\title{
Het instroomniveau voor schoolverlaters op de arbeidsmarkt
}

Citation for published version (APA):

Cörvers, F., \& Lintjens, E. L. M. (2006). Het instroomniveau voor schoolverlaters op de arbeidsmarkt. ROA. ROA Reports No. 008 https://doi.org/10.26481/umarep.2006008

Document status and date:

Published: 01/01/2006

DOI:

10.26481/umarep.2006008

Document Version:

Publisher's PDF, also known as Version of record

\section{Please check the document version of this publication:}

- A submitted manuscript is the version of the article upon submission and before peer-review. There can be important differences between the submitted version and the official published version of record.

People interested in the research are advised to contact the author for the final version of the publication, or visit the DOI to the publisher's website.

- The final author version and the galley proof are versions of the publication after peer review.

- The final published version features the final layout of the paper including the volume, issue and page numbers.

Link to publication

\footnotetext{
General rights rights.

- You may freely distribute the URL identifying the publication in the public portal. please follow below link for the End User Agreement:

www.umlib.nl/taverne-license

Take down policy

If you believe that this document breaches copyright please contact us at:

repository@maastrichtuniversity.nl

providing details and we will investigate your claim.
}

Copyright and moral rights for the publications made accessible in the public portal are retained by the authors and/or other copyright owners and it is a condition of accessing publications that users recognise and abide by the legal requirements associated with these

- Users may download and print one copy of any publication from the public portal for the purpose of private study or research.

- You may not further distribute the material or use it for any profit-making activity or commercial gain

If the publication is distributed under the terms of Article $25 \mathrm{fa}$ of the Dutch Copyright Act, indicated by the "Taverne" license above, 


\section{$\triangle$ \\ Het instroomniveau voor schoolverlaters op de arbeidsmarkt}
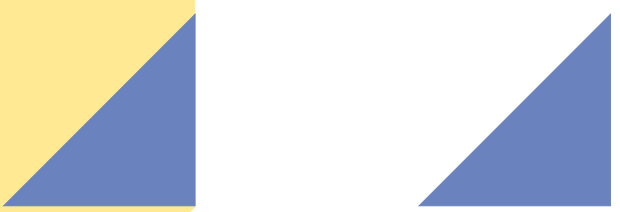

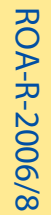
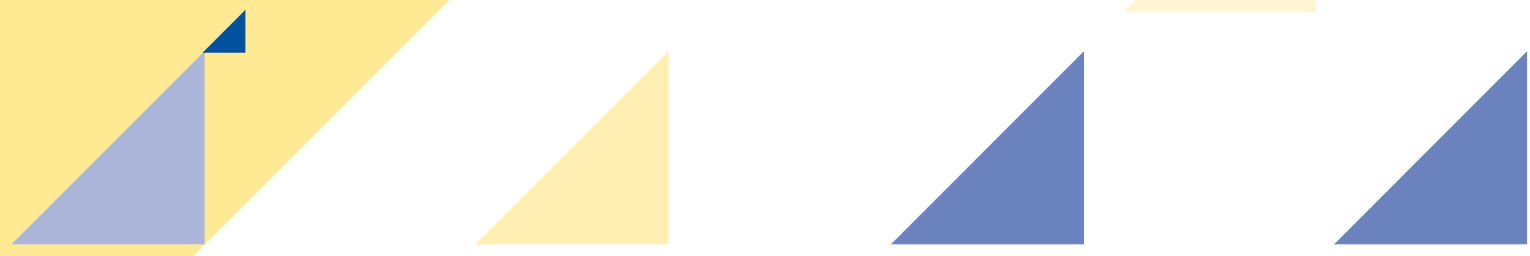

Researchcentrum voor Onderwijs

en Arbeidsmarkt

Research Centre for Education and the Labour Market 


\title{
Het instroomniveau voor schoolverlaters op de arbeidsmarkt
}

\author{
ROA-R-2006/8
}

F. Cörvers

E. Lintjens

Researchcentrum voor Onderwijs en Arbeidsmarkt

Faculteit der Economische Wetenschappen en Bedrijfskunde Universiteit Maastricht

Maastricht, juni 2006 
ISBN-10: 90-5321-439-9

ISBN-13: 978-90-5321-439-8

Sec06.066.doc 


\section{Inhoud}

Bladzijde

\section{Voorwoord}

1 Inleiding 1

2 Werkgelegenheid naar opleidingsniveau 3

3 Instroom van schoolverlaters per sector $\quad 5$

$\begin{array}{lll}4 & \text { Onderbenutting van schoolverlaters } & 27\end{array}$

5 Conclusies 29

$\begin{array}{ll}\text { Referenties } & 31\end{array}$

$\begin{array}{ll}\text { Bijlage A } & 33\end{array}$

$\begin{array}{ll}\text { Bijlage B } & 35\end{array}$

$\begin{array}{ll}\text { Bijlage C } & 37\end{array}$ 



\section{Voorwoord}

In het advies van de Raad voor Werk en Inkomen (RWI) d.d. 29 september 2005, Startklaar. Voorstellen voor sluitende aanpak jongeren zonder diploma, werd onder meer geadviseerd:

1. Jongeren die het voortgezet onderwijs verlaten met een diploma, lager dan niveau 2 moeten niet meer als voortijdig schoolverlater worden geregistreerd.

2. De praktijk van een mogelijk verschil tussen sectorstartniveau en startkwalificatieniveau in sommige sectoren moet als een gegeven worden beschouwd. Sociale partners wordt opgeroepen het sectorstartniveau voor hun sector te bepalen.

Naar aanleiding van dit advies heeft het kabinet op verzoek van de Werktop van 1 december 2005 over de 'tripartiete beleidsinzet van werk en scholing', de RWI advies gevraagd om na samenspraak met de BVE-raad en met betrokkenheid van Colo een nader voorstel uit te brengen over de wenselijkheid om naast het niveau van startkwalificatie specifieke startniveaus van sectoren te definiëren.

Het voorliggende onderzoek is verricht in opdracht van de RWI en dient als basisinformatie voor het advies over het sectorstartniveau. 


\section{Inleiding}

Schoolverlaters die een startkwalificatie hebben behaald in het Nederlandse onderwijs moeten in staat geacht worden om een volwaardige plaats op de arbeidsmarkt te veroveren. Het niveau van een startkwalificatie wordt behaald als minimaal de basisberoepsopleiding in het middelbaar beroepsonderwijs - niveau 2 van de kwalificatiestructuur volgens de WEB - met succes is afgesloten. In de Wet Educatie en Beroepsonderwijs worden vanaf 1 augustus 1997 vier kwalificatieniveaus onderscheiden (zie Bijlage A). In grote lijnen wordt de relevantie van een cesuur tussen niveau 1 en 2 voor de arbeidsmarktpositie van schoolverlaters bevestigd door onderzoek van het Max Goote Kenniscentrum en het ROA. ${ }^{1}$

In alle sectoren van de Nederlandse economie werken zowel middelbaar opgeleiden als lager en hoger opgeleiden, elk van een verschillend subniveau en met een andere opleidings- en ervaringsachtergrond. Deze heterogeniteit hangt samen met de vele sterk van elkaar verschillende beroepen, zowel qua niveau als qua richting, die binnen een bedrijfssector worden uitgeoefend. Zo werken in de Basischemie zowel procesoperators als laboranten, mechanisch operators, productieplanners, natuurwetenschappers en zelfs boekhouders, secretaresses en chauffeurs. De veelheid aan beroepen en functies binnen sectoren weerspiegelt de complexiteit van de productieprocessen. Deze productieprocessen veranderen over de tijd, mede onder invloed van technologische en organisatorische veranderingen.

Bovendien hebben werkgevers meestal meerdere mogelijkheden om in hun personeelsbehoefte te voorzien. Afhankelijk van de schaarste op de arbeidsmarkt en het beschikbare arbeidsaanbod kunnen zij de werving en selectie van personeel intensiveren of richten op andere doelgroepen, bijv. op schoolverlaters die niet geheel voldoen aan het opleidingsprofiel qua niveau en richting, op potentiële baanwisselaars van andere bedrijven (evt. in andere sectoren), en op buitenlands personeel. Daarnaast kunnen werkgevers de organisatie van de werkprocessen anders inrichten, functies anders definiëren, interne opleidingstrajecten opstarten, leerlingplaatsen (beroepsbegeleidende leerweg) aanbieden, afspraken maken met ROC's over het curriculum van (nieuwe) opleidingen, etc.

Voorts hangt het opleidingsniveau van werkenden in een sector samen met hun loopbaan binnen de organisatie of bedrijfstak. Voor schoolverlaters kan bijvoorbeeld een assistentenopleiding (niveau 1) nog voldoende zijn om aangenomen te worden, na verloop van tijd zal deze schoolverlater zich veelal moeten ontwikkelen tot een werknemer die complexere werkzaamheden kan verrichten, een grotere zelfstandigheid heeft en meer verantwoordelijkheden kan dragen, jongere werknemers kan aansturen of begeleiden, etc. Een dergelijke doorgroei binnen organisaties duidt op

1. Zie Houtkoop et al. (2004) en Van der Velden et al. (2002). Er is gekeken naar hoe de arbeidsmarktpositie van schoolverlaters verbetert door een extra opleidingsjaar. Daarbij zijn verschillende indicatoren voor de arbeidsmarktpositie gebruikt, o.a. deelname aan beroepsbevolking of vervolgonderwijs, betaald werk, vast werk, etc. 
een stijgende productiviteit die samenhangt met een stijgend loonniveau gedurende de loopbaan. Werknemers die een dergelijke productiviteitsgroei niet doormaken lopen een groter risico dat hun arbeidscontract niet verlengd of verbroken wordt (evt. ontslag). Voor veel laag opgeleiden dreigt er op den duur non-participatie als ze zich niet opscholen naar een hoger opleidingsniveau. ${ }^{2}$

In het voorliggende rapport wordt gekeken naar het meest gangbare niveau waarmee gediplomeerde schoolverlaters aan de slag gaan in de verschillende sectoren van de Nederlandse economie. Bovendien wordt voor elk van de 34 sectoren $^{3}$ gekeken naar de mate waarin schoolverlaters werkzaamheden uitvoeren die ook door schoolverlaters van een lager opleidingsniveau kunnen worden uitgevoerd, de zogenaamde onderbenutting van de competenties van schoolverlaters. De opleidingsniveaus die worden onderscheiden zijn: het Voorbereidend Middelbaar Beroepsonderwijs (VMBO), de vier kwalificatieniveaus van het Middelbaar Beroepsonderwijs (MBO, zie Bijlage A), het Hoger Algemeen Vormend Onderwijs en het Voorbereidend Wetenschappelijk Onderwijs (samen aangeduid als HAVO/VWO), het Hoger Beroepsonderwijs (HBO) en het Wetenschappelijk Onderwijs (WO). In het kader van het onderzoek worden geen leerwegen op het VMBO en MBO onderscheiden.

In de volgende paragraaf wordt de verdeling van de werkgelegenheid naar drie opleidingsniveaus aangegeven. Deze paragraaf dient slechts ter illustratie van het belang van het lager, middelbaar en hoger onderwijs onder de totale groep van werkenden (i.e. niet uitsluitend schoolverlaters) voor de verschillende sectoren in Nederland.

In de derde paragraaf wordt ingegaan op de verdeling van de instroom van schoolverlaters naar opleidingsniveau in elk van deze sectoren. Het gaat hierbij in het bijzonder om de vraag welk opleidingsniveau het meeste voorkomt onder de jongeren die - aan het begin van hun loopbaan - aan het werk gaan in een bepaalde sector.

Vervolgens wordt in de vierde paragraaf informatie gegeven over de mate van onderbenutting van de competenties van schoolverlaters met een startkwalificatie (vanaf niveau 2) die in een sector werkzaam zijn. Een grote onderbenutting van schoolverlaters van een bepaald opleidingsniveau in een sector geeft aan dat de schoolverlaters van het betreffende opleidingsniveau relatief vaak overgekwalificeerd zijn voor het niveau waarop de werkzaamheden worden uitgevoerd. In de laatste paragraaf volgen de conclusies.

2. Zie hoofdstuk 5 in ROA (2003).

3. Zie ROA (2002) voor de koppeling tussen de ROA-sectorindeling en de Standaard Bedrijfsindeling (SBI '93) van het CBS. 


\section{Werkgelegenheid naar opleidingsniveau}

In deze paragraaf gaan we dieper in op de werkgelegenheid per opleidingsniveau voor alle 34 bedrijfssectoren. Zoals eerder opgemerkt dient deze paragraaf slechts ter illustratie van het belang van het lager, middelbaar en hoger onderwijs onder de totale groep van werkenden (i.e. niet uitsluitend schoolverlaters) voor de verschillende sectoren in Nederland. Voor de analyse in deze paragraaf wordt er onderscheid gemaakt tussen drie opleidingsniveaus ${ }^{4}$ :

- Lager opgeleiden zijn werkenden met uitsluitend Basisonderwijs (i.e. ongeschoold), VMBO, en bol/bbl niveau 1 van het MBO;

- Middelbaar opgeleiden zijn werkenden met een opleiding van het MBO, dat wil zeggen met bol en bbl niveau 2, 3 en 4, of HAVO/VWO;

- Hoger opgeleiden zijn werkenden met een HBO- of WO-opleiding.

Figuur 2.1 geeft het percentage werkenden naar opleidingsniveau in 34 bedrijfssectoren weer. De gegevens zijn gebaseerd op gemiddelde aantallen voor de periode 2003-2004 uit de Enquête Beroepsbevolking van het CBS. In Bijlage B is de volledige tabel met de gegevens naar vijf opleidingsniveaus opgenomen.

De figuur laat zien dat het percentage lager opgeleiden onder de werkenden het grootst is in de sectoren textiel, hout- en bouwmaterialen en weg- en railvervoer. Het percentage middelbaar opgeleiden het grootst is in de sectoren Overige commerciële dienstverlening en Veehouderij. Hier heeft $54 \%$ van de werkenden een diploma op middelbaar niveau. Ook in de sectoren Energie, Machine-industrie en Bouw heeft meer dan helft van de werkenden een middelbaar opleidingsniveau. In de Horeca, Verzekeringswezen, Handel en reparatie en Grafische industrie is dat de helft.

Voor de bedrijfssectoren met veel middelbaar opgeleiden geldt dat het aandeel lager opgeleiden nogal verschilt per sector. In de Veehouderij, Bouw, Horeca en Handel en reparatie heeft ruim een derde een middelbaar diploma, in het Verzekeringswezen en de Energie is dat ongeveer 15\%. Dat betekent dat het gemiddelde opleidingsniveau - gemiddelde aantal jaren scholing dat is genoten door alle werkenden in een sector - aanzienlijk kan afwijken tussen sectoren met relatief veel middelbaar opgeleiden.

Bedrijfssectoren met relatief weinig middelbaar opgeleiden zijn de Vlees- en visverwerking, Tuinbouw, Elektrotechniek, Hout- en bouwmaterialen, Zakelijke dienstverlening, Overige kwartaire diensten, en het Onderwijs heeft $40 \%$ of minder een opleiding op middelbaar niveau. Ook hier geldt dat het aandeel lager (en dus ook hoger) opgeleiden aanzienlijk kan verschillen tussen sectoren.

4. Opleidingen die voorheen door een groot deel van de beroepsbevolking zijn afgesloten worden door het CBS eveneens geclassificeerd naar niveau en richting. Denk hierbij aan opleidingen zoals LTS en MTS, Mulo, HBS, MBO kort en lang, en primair leerwezen, etc. 
Vooral Onderwijs en Overige kwartaire diensten worden gekenmerkt door een laag aandeel van zowel middelbaar en lager opgeleiden. In deze twee bedrijfssectoren zijn de hoger opgeleiden duidelijk in de meerderheid.

Figuur 2.1

Percentage werkenden naar opleidingsniveau in 34 bedrijfssectoren, gemiddelde 2003-2004

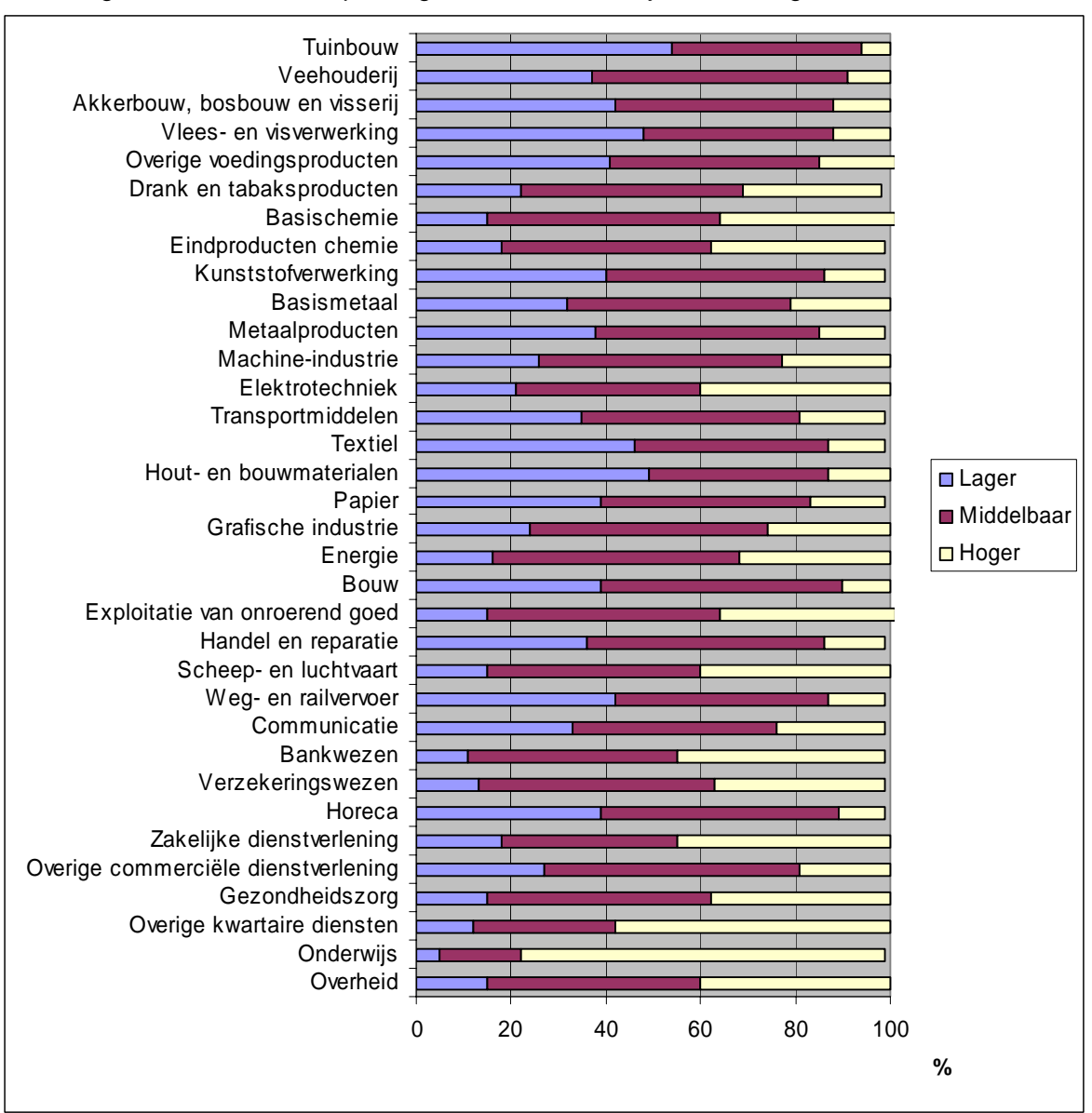

De figuur laat zien dat het percentage middelbaar opgeleiden het grootst is in de sectoren Overige commerciële dienstverlening, Veehouderij, Energie, Bouw en Machine-industrie. Meer dan de helft van alle werkenden in deze sectoren heeft een middelbaar diploma op zak. Terwijl in de Tuinbouw, Hout- en bouwmaterialen en Vlees- en visverwerking relatief veel lager opgeleiden werkzaam zijn.

Onderwijs en Overige kwartaire diensten, daarentegen, worden gekenmerkt door een lage vertegenwoordiging van zowel middelbaar en lager opgeleiden. In deze 2 bedrijfssectoren zijn de hoger opgeleiden duidelijk in de meerderheid. Andere sectoren met $40 \%$ of meer hoger opgeleide werkenden zijn Elektrotechniek, Scheepen luchtvaart, Bankwezen, Zakelijke Dienstverlening en Overheid. 


\section{Instroom van schoolverlaters per sector}

In deze paragraaf wordt ingegaan op de instroom van jongeren die het lager en middelbaar onderwijs succesvol hebben afgesloten en zich aanbieden op de arbeidsmarkt. Deze schoolverlaters gaan aan het werk in één van de 34 bedrijfssectoren die in dit rapport worden onderscheiden. In het kader van de centrale vraagstelling wordt gekeken naar hoeveel middelbaar opgeleide schoolverlaters werkzaam zijn in de verschillende bedrijfssectoren anderhalf jaar na het behalen van het diploma. Er wordt gebruik gemaakt van het Schoolverlatersinformatiesysteem (SIS) van het ROA waarin de verschillende monitors van schoolverlaters en afgestudeerden zijn geïntegreerd. Door dit systeem kan de transitie van school naar werk over de volle breedte van het onderwijs worden geanalyseerd ${ }^{5}$.

In deze paragraaf wordt per bedrijfssector gekeken naar de verdeling van de instroom van schoolverlaters naar opleidingsniveau in de verschillende bedrijfssectoren gedurende de zesjaarsperiode 1999-2004 ${ }^{6}$. De lager en middelbaar opgeleiden zijn opgesplitst in schoolverlaters van respectievelijk VMBO en de vier kwalificatieniveaus op het MBO. Omdat er weinig schoolverlaters zijn van niveau 1 op het MBO (zie Bijlage C), en omdat uit eerder onderzoek (zie paragraaf 1) is gebleken dat dit kwalificatieniveau zich onderscheid van niveau 2, zijn bij de presentatie in deze paragraaf de schoolverlaters van niveau 1 samengevoegd met de schoolverlaters van het VMBO. In de beschrijving van sectoren hieronder wordt wel aangegeven waar niveau 1 een significante rol speelt bij de instroom van schoolverlaters. De hoger opgeleiden zijn opgesplitst in afgestudeerden van het HBO en WO.

In Bijlage $\mathrm{C}$ wordt de arbeidsmarktinstroom van schoolverlaters per bedrijfssector zoveel mogelijk uitgesplitst naar de verschillende kwalificatieniveaus binnen het MBO en de overige opleidingsniveaus (VMBO, HAVO/VWO, $\mathrm{HBO}$ en WO). Per bedrijfssector wordt er uitsluitend gekeken naar de verdeling van de gediplomeerde instroom. Dat wil zeggen dat voortijdig schoolverlaters (o.a. ongeschoolden) en andere ongediplomeerden die het onderwijs verlaten en op de arbeidsmarkt terecht komen, niet zijn meegenomen in de analyse.

De 34 bedrijfssectoren zijn gegroepeerd in 13 clusters van min of meer verwante bedrijfssectoren. Figuur 3.1 laat de verdeling van de instroom van schoolverlaters zien voor drie sectoren binnen het cluster Landbouw en visserij. Er blijkt dat schoolverlaters van het $\mathrm{VMBO}$ /niveau 1 veruit de grootste groep vormen binnen de Tuinbouw. Eén derde van de instroom in de sector Tuinbouw bestaat uit gediplomeerden van dit laagste niveau. Niveau 4 levert de grootste instroom van

5. Zie www.roa.unimaas.nl/sis/index.htm en ROA (2005) voor meer informatie.

6. Het meetmoment van de bedrijfssector van de werkzame schoolverlaters is anderhalf jaar na het verlaten van de opleiding. 
MBO'ers, hoewel het verschil met niveau 2 of 3 klein is. In totaal is $87 \%$ van de instroom van schoolverlaters lager of middelbaar opgeleid.

Figuur 3.1

Opleidingsniveau van gediplomeerde schoolverlaters die instromen in de Landbouw en visserij, 1999-2004
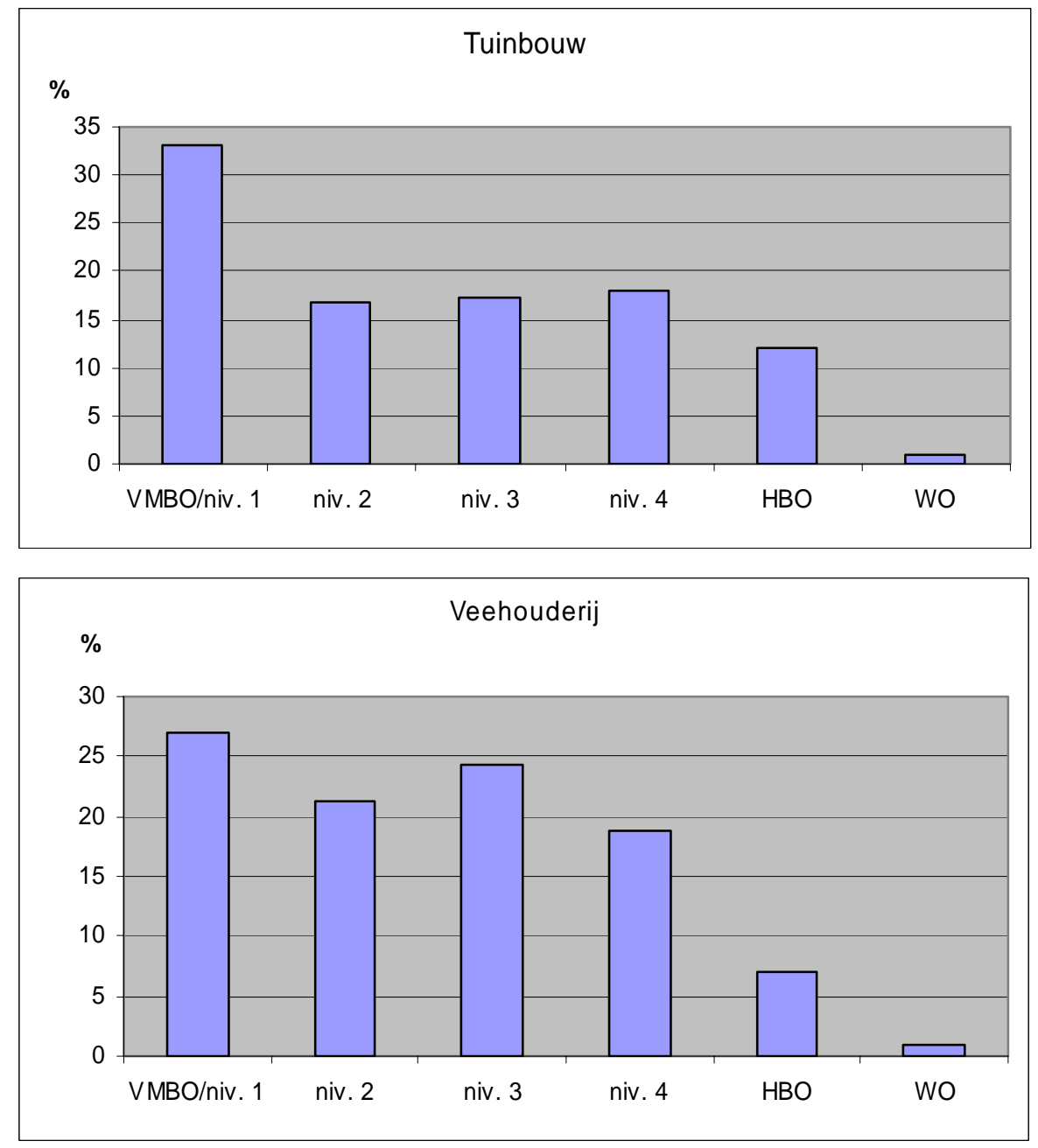


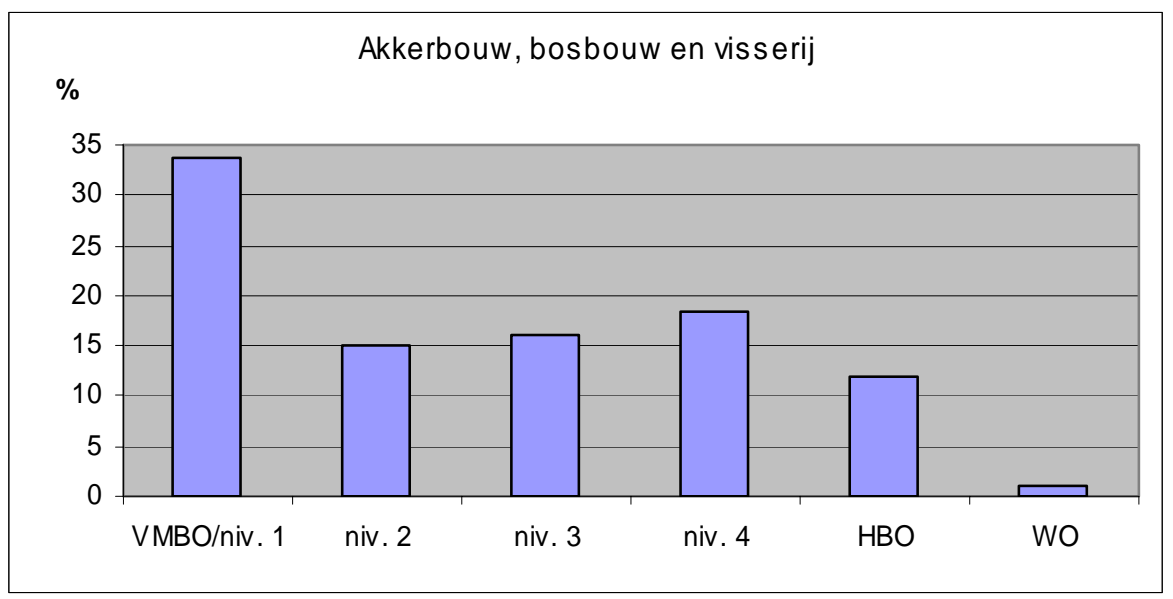

De Veehouderij spant de kroon wat betreft de instroom van lager en middelbaar opgeleiden: maar liefst $92 \%$ van de gehele instroom van schoolverlaters heeft maximaal niveau 4. Wederom vormt VMBO/niveau 1 de grootste groep instromers (27\%), onder wie relatief veel schoolverlaters (ruim 7\%, zie Bijlage C) met niveau 1. De Veehouderij heeft van alle sectoren het grootste aandeel van schoolverlaters die met niveau 1 instromen. Zoals eerder opgemerkt speelt de instroom van schoolverlaters van niveau 1 voor de meeste sectoren nauwelijks een rol. Niveau 3 is het meest gangbare kwalificatieniveau van de MBO'ers die instromen in de Veehouderij.

Voor de Akkerbouw, bosbouw en visserij komt VMBO/niveau 1 het meeste voor (34\%). Op de middelbare en hogere opleidingsniveaus levert niveau 4 de grootste instroom.

Figuur 3.2 laat de verdeling van de instroom zien voor de drie sectoren binnen de Voeding. In de Vlees- en visverwerking vormen de schoolverlaters die instromen met een lager niveau of een HBO-opleiding de belangrijkste groepen. Voor de schoolverlaters van het MBO vormt niveau 2 de grootste groep.

Voor de sector Overige voedingsproducten is niveau 2 het meest voorkomende kwalificatieniveau. De instroom van schoolverlaters in de sector Overige voedingsproducten is sterk afhankelijk van de instroom van de laagste twee niveaus (VMBO/niveau 1 en niveau 2) en van het $\mathrm{HBO}$.

Voor de sector Drank en tabaksproducten is de instroom echter grotendeels afhankelijk van de hogere opleidingsniveaus. Niet alleen komt niveau 4 het meeste voor onder de lager en middelbaar opgeleiden, bovendien is ruim de helft van de ingestroomde schoolverlaters afkomstig van het hoger onderwijs. 
Figuur 3.2

Opleidingsniveau van gediplomeerde schoolverlaters die instromen in de Voeding, 1999-2004
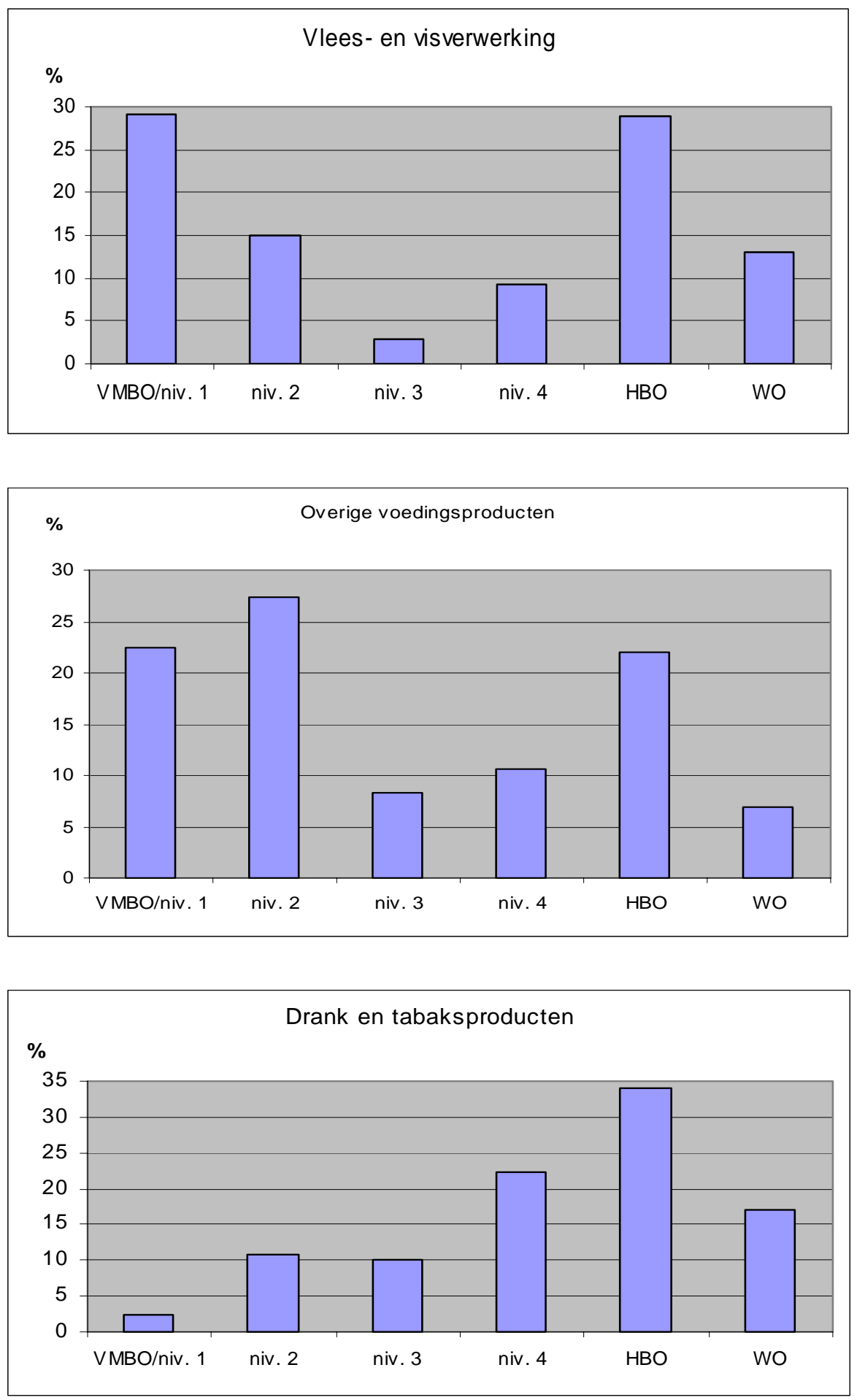
In figuur 3.3 is de instroom van schoolverlaters weergegeven voor de drie sectoren binnen de Chemie. Binnen de Basischemie komen niveau 4 en HBO het meest voor onder de schoolverlaters die instromen. Voor de Eindproducten chemie werken vooral veel hoger opgeleiden. De instroom van niveau 2 is net iets groter dan de instroom van niveau 4 ..

Figuur 3.3

Opleidingsniveau van gediplomeerde schoolverlaters die instromen in de Chemie, 1999-2004
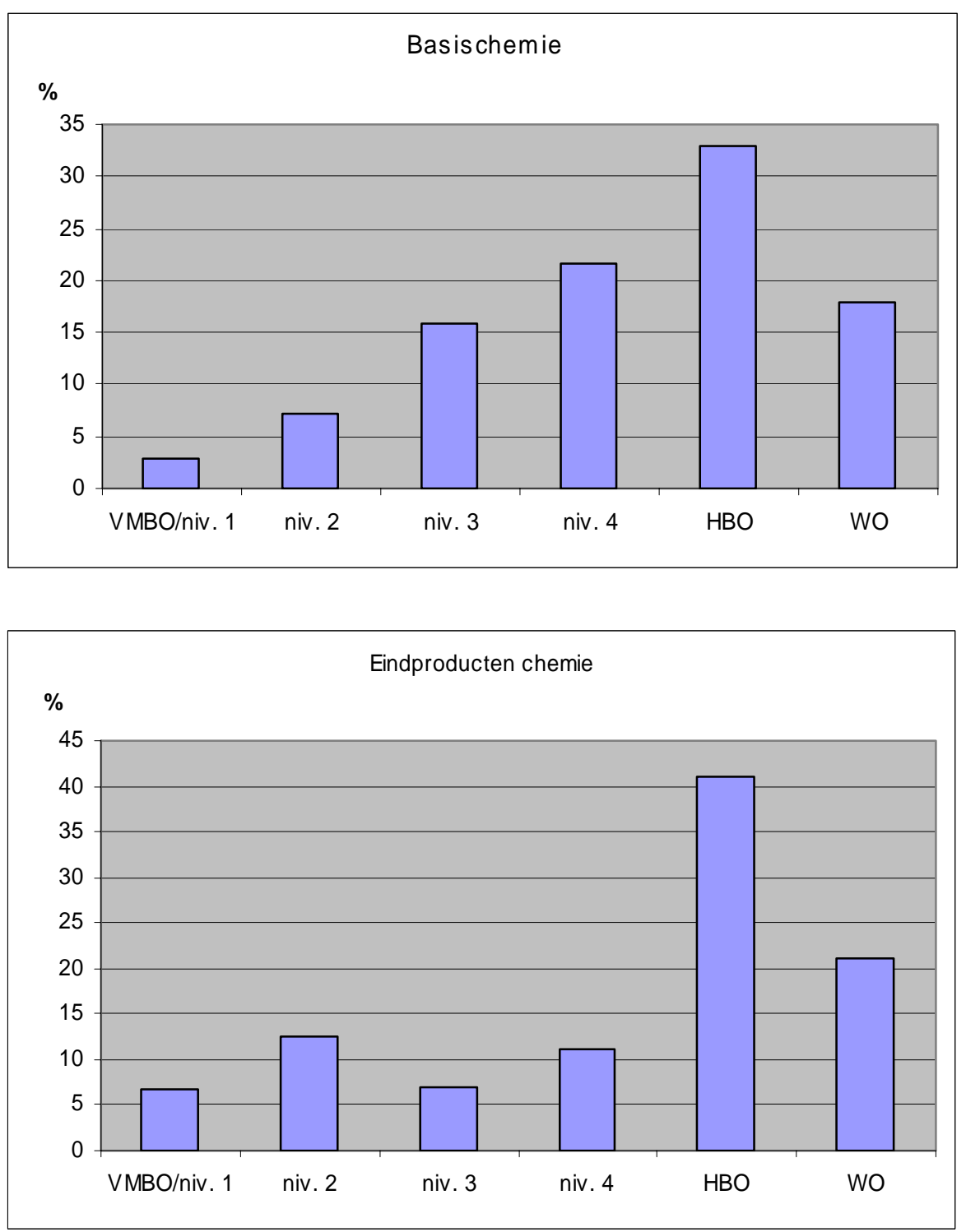


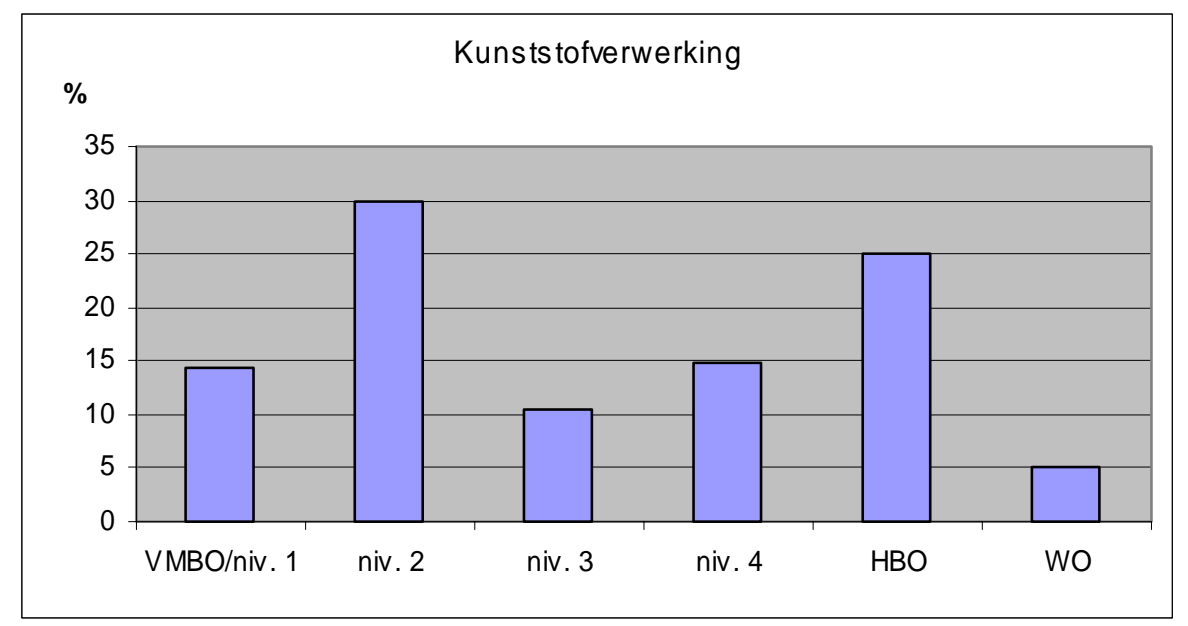

In tegenstelling tot de geringe instroom van lager opgeleiden voor de Basischemie en Eindproducten chemie wordt de Kunststofverwerking gekenmerkt door een grote instroom van lager en middelbaar opgeleiden (70\%). De grootste groep wordt hier gevormd door schoolverlaters van niveau 2 (30\%). Toch bestaat nog altijd $25 \%$ van de instroom in deze sector uit HBO'ers.

Figuur 3.4 laat de instroom zien van lager en middelbaar opgeleiden zien voor de vijf sectoren binnen de Metaal en elektrotechniek. De grootste groep van instromers in de Basismetaal is afkomstig van het $\mathrm{HBO}$. Het meest voorkomende niveau van lager en middelbaar opgeleiden binnen de Basismetaal is VMBO/niveau 1 (23\%). Van de instromers van het MBO heeft een iets groter deel een diploma op niveau 4 dan op niveau 2. Er stromen slechts weinig schoolverlaters in met niveau $3(2 \%)$.

Binnen de sector Metaalproducten gaan veel schoolverlaters van een lager of middelbaar opleidingsniveau aan de slag (81\%). De meerderheid wordt daarbij gevormd door schoolverlaters van VMBO/niveau 1 (33\%) en niveau 2 (28\%). Binnen de Machine-industrie is de grootste groep afkomstig van het HBO. Ook binnen de Machine-industrie komen VMBO/niveau 1 (23\%) en niveau 2 (19\%) veel voor. Bijna twee derde van de instroom bestaat uit lager en middelbaar opgeleiden. 
Figuur 3.4

Opleidingsniveau van gediplomeerde schoolverlaters die instromen in de Metaal en elektrotechniek, 1999-2004
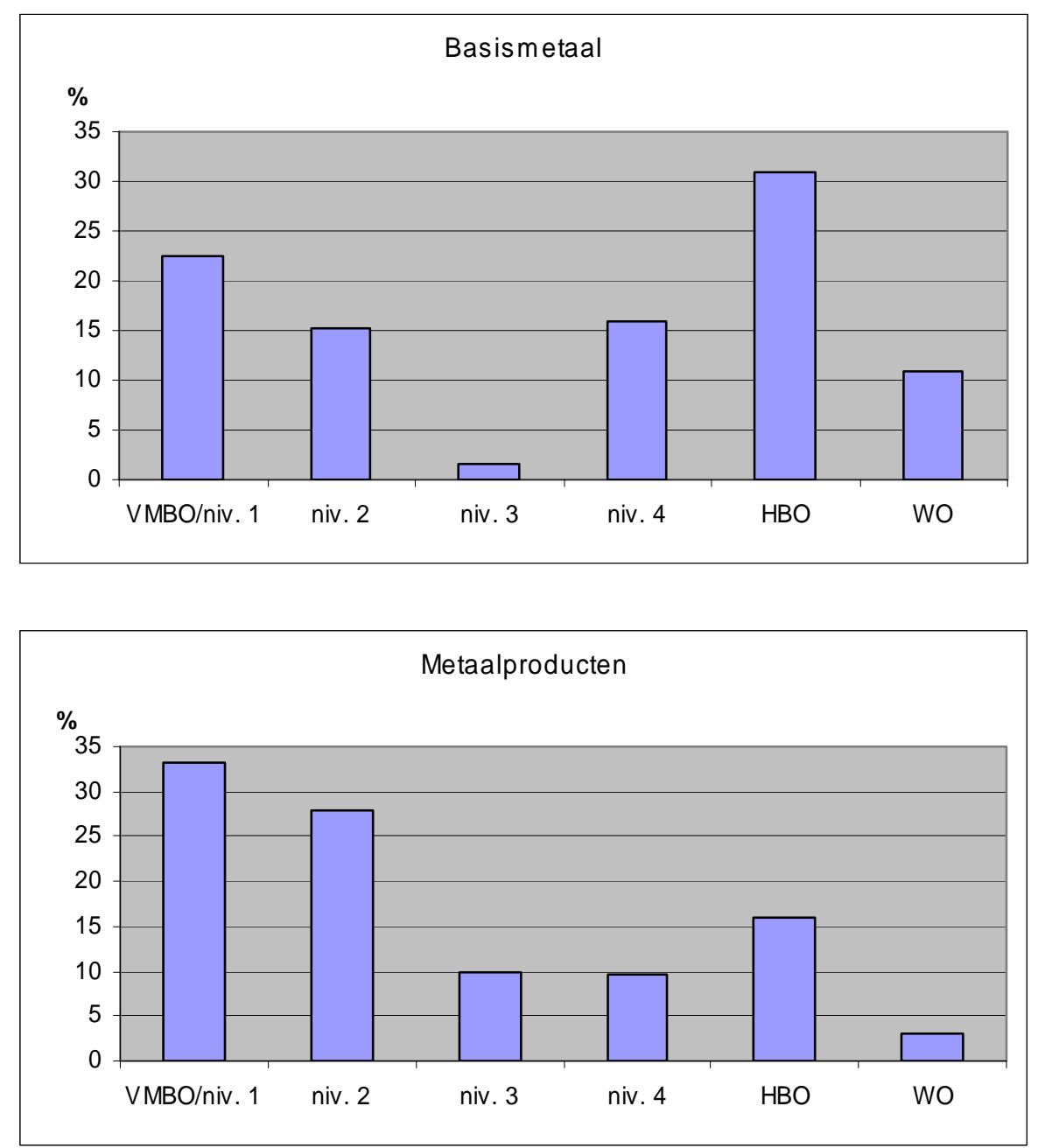

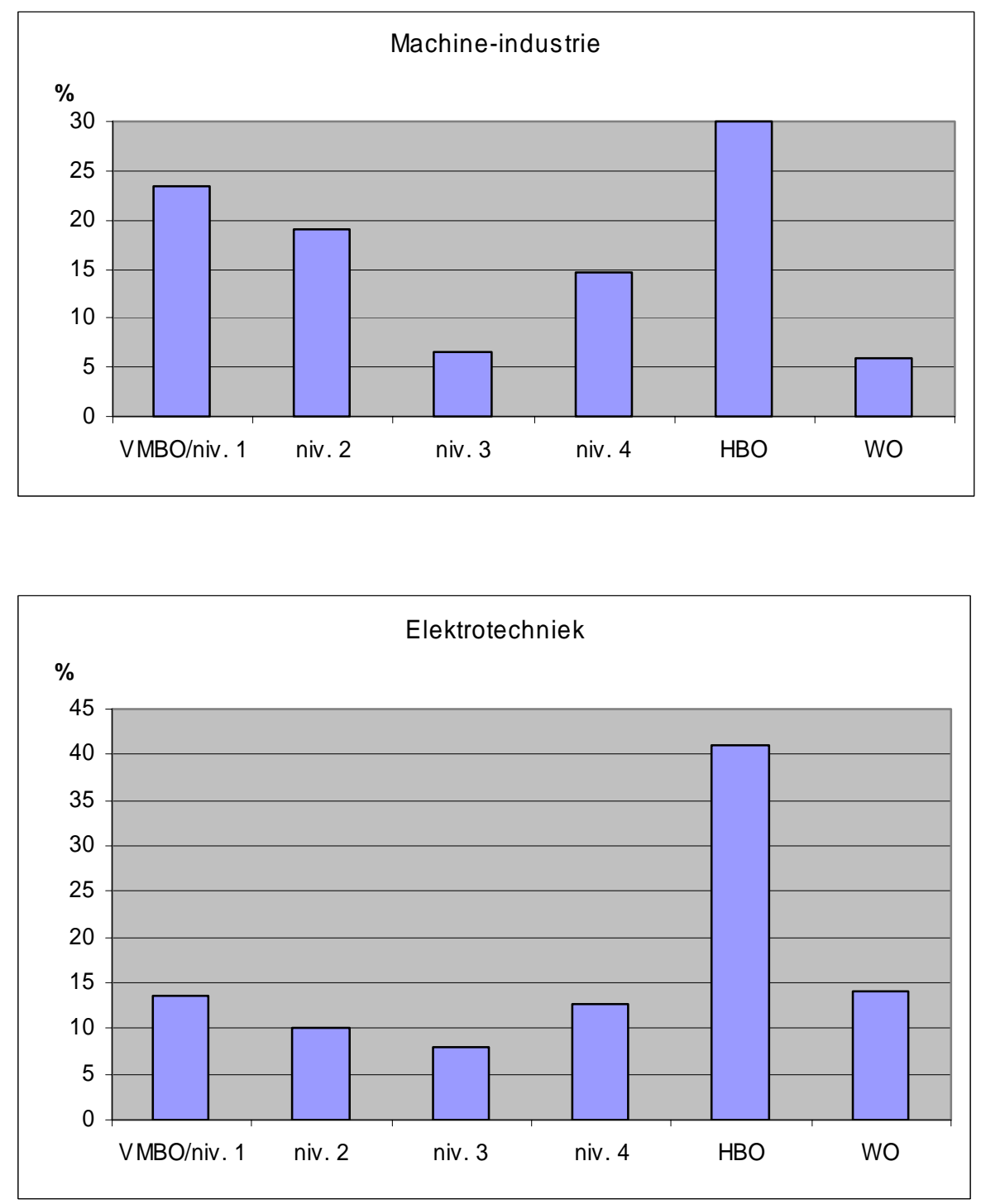


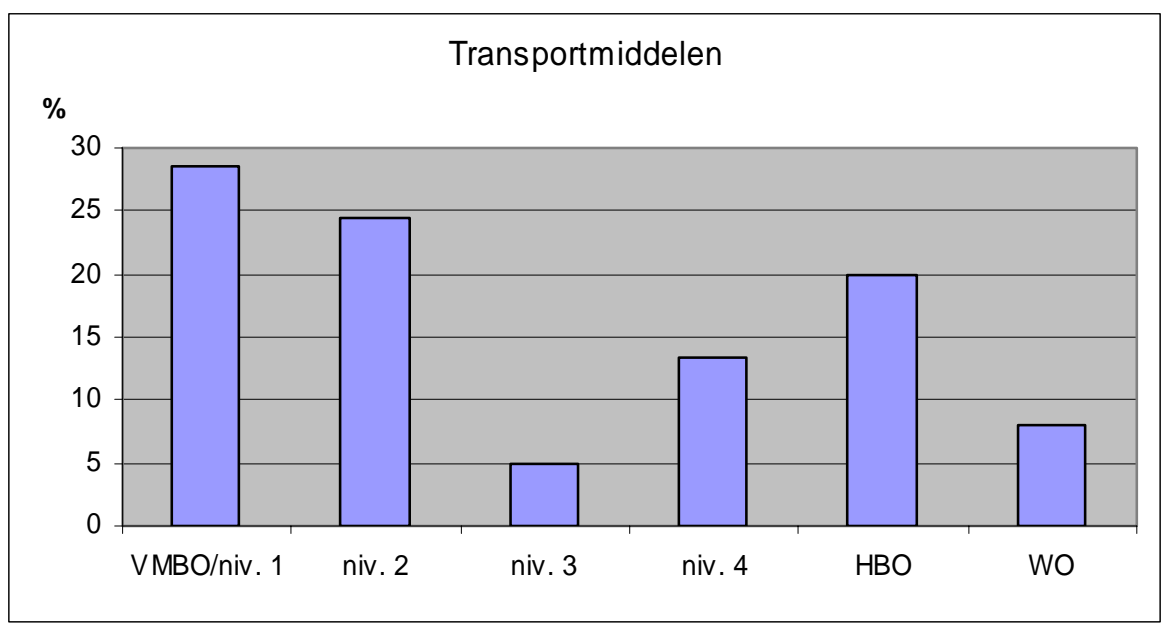

De instroom in de sector Elektrotechniek wordt daarentegen gekenmerkt door een meerderheid van hoger opgeleiden (55\%). De grootste groep binnen de lager en middelbaar opgeleiden zijn de schoolverlaters van niveau 4 (13\%). De totale groep schoolverlaters van $\mathrm{VMBO}$ /niveau 1 is weliswaar groter (14\%), maar een deel van deze schoolverlaters heeft niveau 1.

De instroom in Transportmiddelen bestaat voornamelijk uit lager en middelbaar opgeleiden $(72 \%)$. Het leeuwendeel wordt gevormd door schoolverlaters van VMBO/niveau 1 (29\%, waarbij 24\% VMBO) en niveau 2 (ruim 24\%). Niveau 2 komt iets vaker voor dan $\mathrm{VMBO}$, omdat bijna $5 \%$ van de totale instroom het kwalificatieniveau 1 heeft behaald (zie Bijlage C).

Figuur 3.5 geeft de verdeling van de schoolverlaters die instromen weer voor de voor sectoren binnen de Overige industrie. Textiel heeft een hoog percentage lager en middelbaar opgeleiden onder de schoolverlaters die instromen (72\%). Het meest voorkomende niveau is hier niveau $2(28 \%)$. Niveau 3 is wederom de kleinste groep $(2 \%)$.

Ook Hout- en bouwmaterialen is qua instroom van schoolverlaters voor het merendeel afhankelijk van de lager en middelbaar opgeleiden (84\%). Deze schoolverlaters hebben veelal niveau $2(30 \%)$. Opmerkelijk is verder dat er binnen deze sector, evenals binnen de Veehouderij, relatief veel schoolverlaters van niveau 1 aan het werk zijn (dat wil zeggen exclusief VMBO: $6 \%$ ).

Ook het merendeel van de instroom in de Papiersector is van lager of middelbaar opleidingsniveau (57\%), hoewel de grootste groep een HBO-achtergrond heeft $(30 \%)$. Het meest voorkomende niveau is niveau $4(16 \%)$. De verschillen tussen de aandelen van de kwalificatieniveaus 2 tot en met 4 zijn echter klein. 
Binnen de Grafische industrie worden relatief veel hoger opgeleiden gevraagd: zij vormen de meerderheid (56\%) binnen de instromers. Onder de lager en middelbaar opgeleiden heeft de grootste groep een opleiding gevolgd op VMBO/niveau 1 (15\% van de totale instroom) en niveau 4 (12\%).

\section{Figuur 3.5}

Opleidingsniveau van gediplomeerde schoolverlaters die instromen in de Overige industrie, 1999-2004
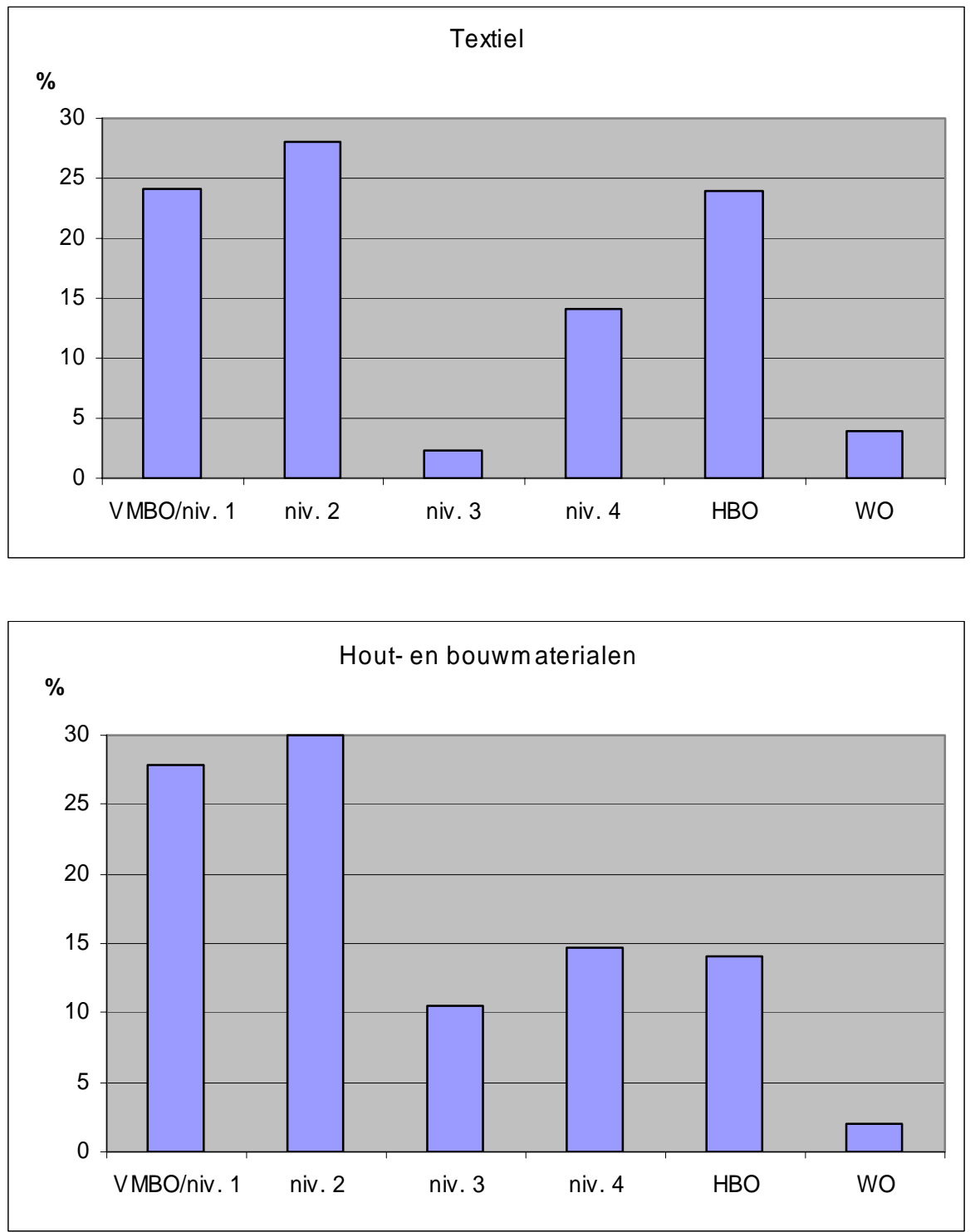

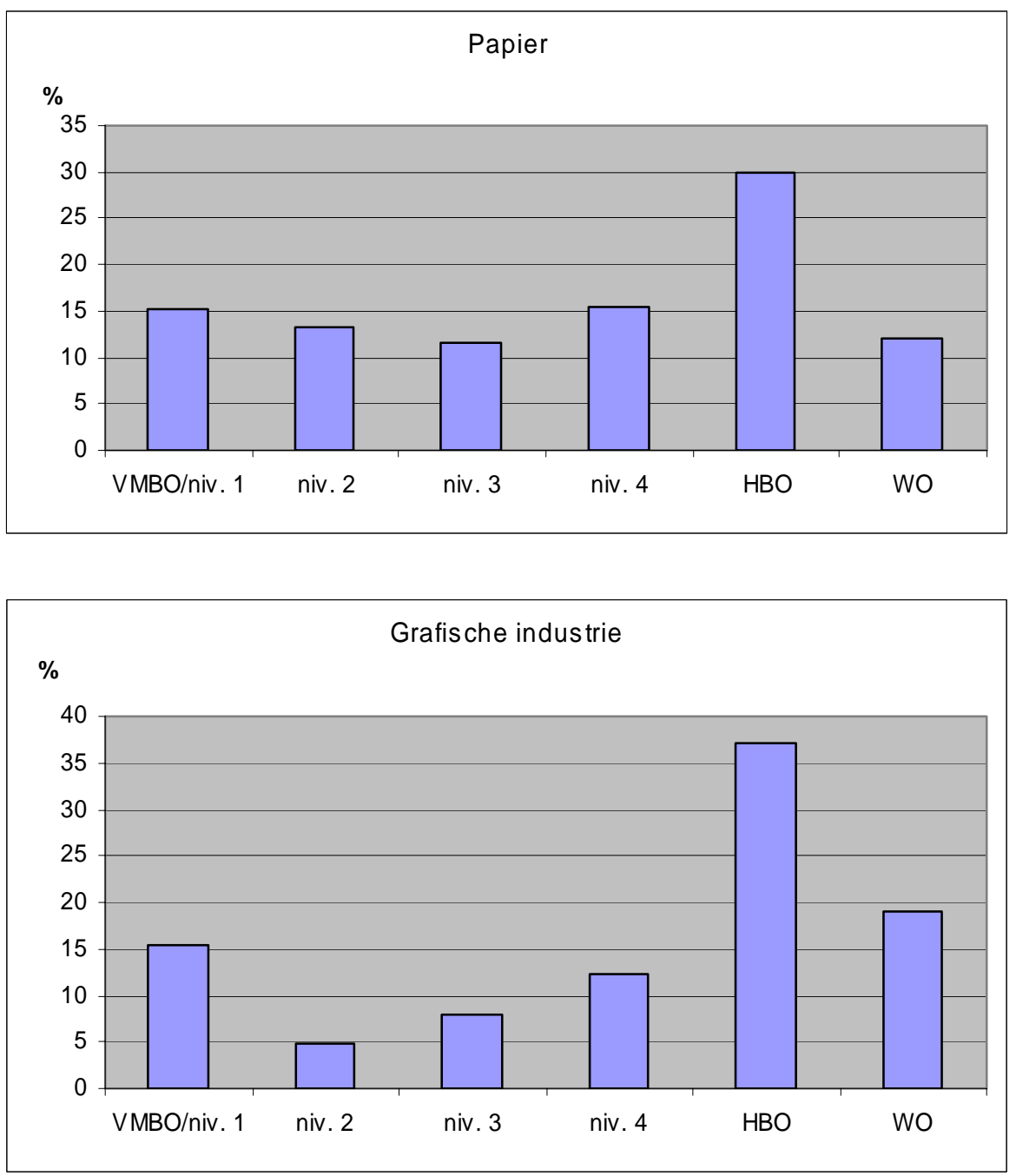

Figuur 3.6 illustreert voor Energie dat de instroom van lager en middelbaar opgeleiden relatief gering is en dat hoger opgeleiden in de meerderheid zijn (57\%). Het meest voorkomende niveau van de instroom onder lager en middelbaar opgeleiden is niveau 4 (18\%). In de Energie zijn de kwalificatievereisten dus hoog, zoals ook blijkt uit het grote aandeel hoger opgeleiden. 
Figuur 3.6

Opleidingsniveau van gediplomeerde schoolverlaters die instromen in de Energie, 1999-2004

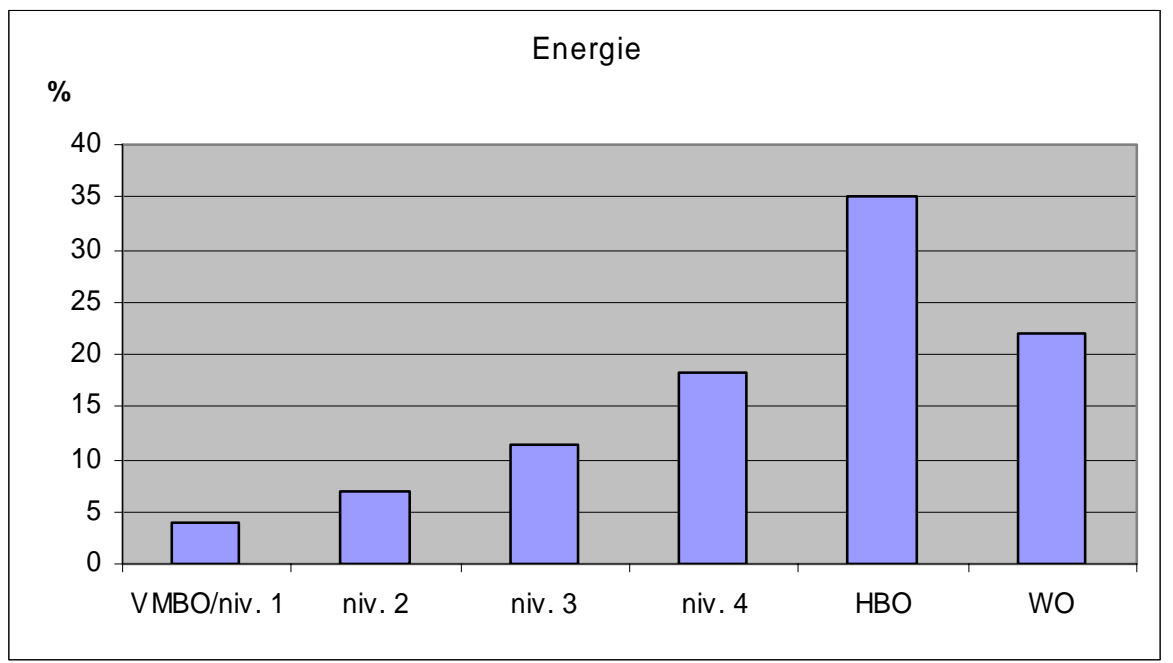

Figuur 3.7 laat de kwalificatiestructuur zien van de instroom van schoolverlaters in twee sectoren van de Bouw en onroerend goed. De lager en middelbaar opgeleiden hebben het grootste aandeel in de instroom in de Bouw (91\%). Na de Veehouderij heeft deze sector de grootste relatieve instroom van lager en middelbaar opgeleiden. $\mathrm{VMBO} /$ niveau 1 komt daarbij relatief het vaakst voor. Deze sector lijkt zich voornamelijk te richten op de lager opgeleiden en niveau 2 bij de werving van jong personeel.

In tegenstelling tot de Bouwsector is in de sector Exploitatie van onroerend goed minder dan de helft van de instroom van schoolverlaters afkomstig van lager en middelbaar opleidingsniveau (42\%). De grootste groep van instromers heeft een HBO-diploma gehaald (42\%), terwijl er heel weinig schoolverlaters van VMBO/niveau 1 instromen. 
Figuur 3.7

Opleidingsniveau van gediplomeerde schoolverlaters die instromen in de Bouw en onroerend goed, 1999-2004
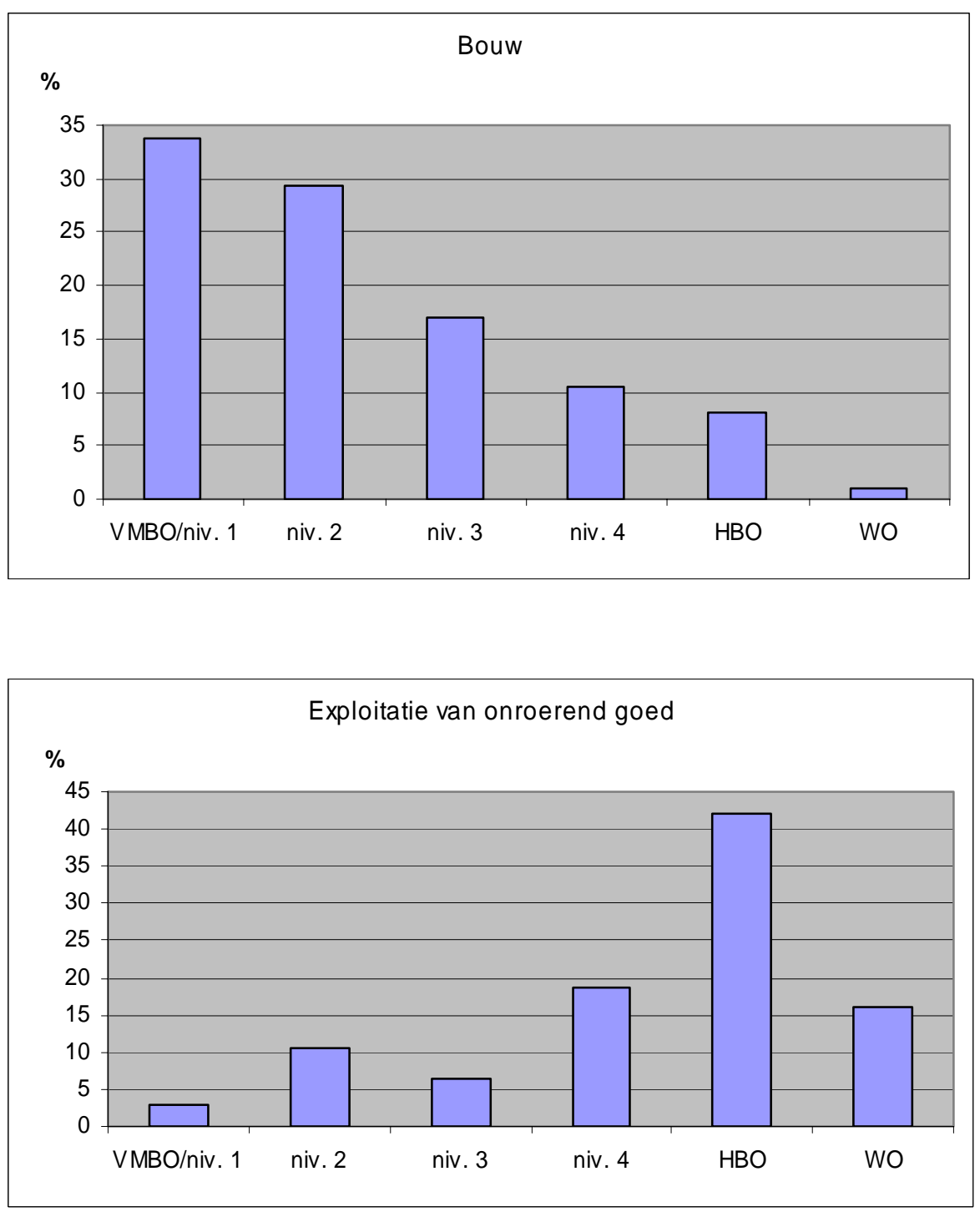

In figuur 3.8 is de instroom van schoolverlaters in de Handel en reparatie weergegeven. We kunnen concluderen we dat deze sector gekenmerkt wordt door een aanzienlijke instroom van lager en middelbaar opgeleiden (84\%). De meest voorkomende niveau is hier VMBO/niveau 1. Dus voor deze sector zijn vooral de laag gekwalificeerde arbeidskrachten heel belangrijk. Verder stromen er iets meer schoolverlaters van niveau 2 in dan van niveau 4. 
Figuur 3.8

Opleidingsniveau van gediplomeerde schoolverlaters die instromen in de Handel en reparatie, 1999-2004

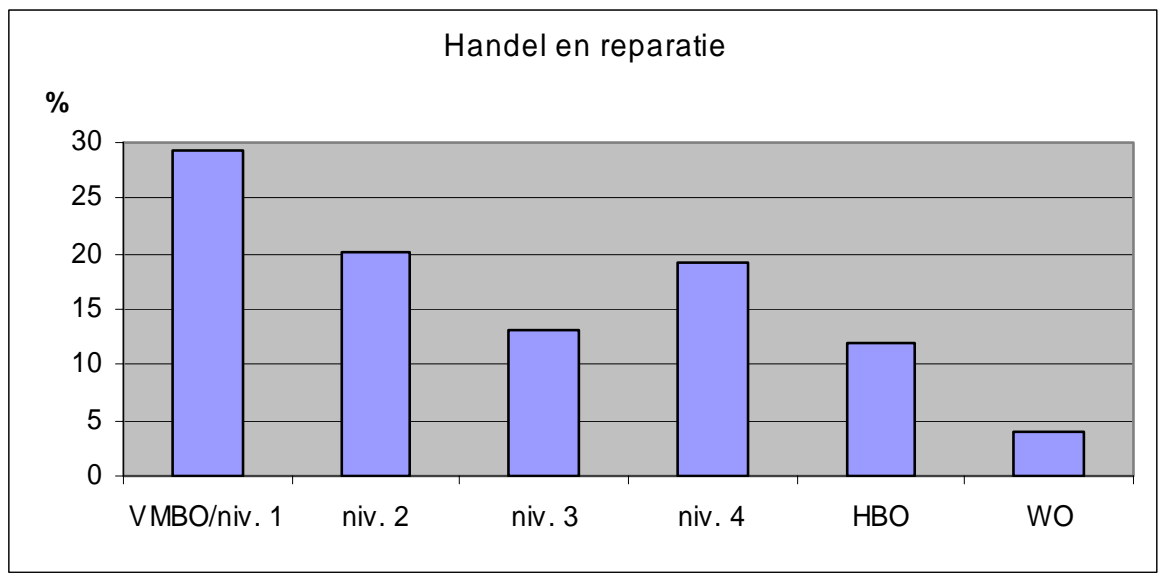

Figuur 3.9 laat de verdeling van de instroom zien voor de sectoren binnen Transport en communicatie. Voor de Scheepvaart- en luchtvaart blijkt dat het HBO-niveau onder de instromers het meest gangbaar is (32\%). Niveau 4 is het belangrijkste is $(22 \%)$ voor de werving van lager en middelbaar opgeleiden. De lager en middelbaar opgeleiden vormen $58 \%$ van de totale instroom van schoolverlaters. Niveau 2 en niveau 3 komen relatief weinig voor.

Ook voor het Weg- en railvervoer zijn lager en middelbaar opgeleiden ruim in de meerderheid; bijna drie kwart van de instroom (73\%) heeft een VMBO- of MBOdiploma behaald. Het meest voorkomende niveau is niveau $2(26 \%)$. Niveau 3 komt slecht weinig voor.

Lager en middelbaar opgeleiden zijn daarentegen in de minderheid onder de schoolverlaters die aan het werk gaan in de sector Communicatie (43\%). In deze sector heeft $40 \%$ van de instromers een $\mathrm{HBO}$-achtergrond. In samenhang met de relatief hoge kwalificatievereisten is niveau 4 het meest voorkomende kwalificatieniveau onder de lager en middelbaar opgeleide instroom van schoolverlaters $(20 \%)$. 
Figuur 3.9

Opleidingsniveau van gediplomeerde schoolverlaters die instromen in de Transport en communicatie, 1999-2004
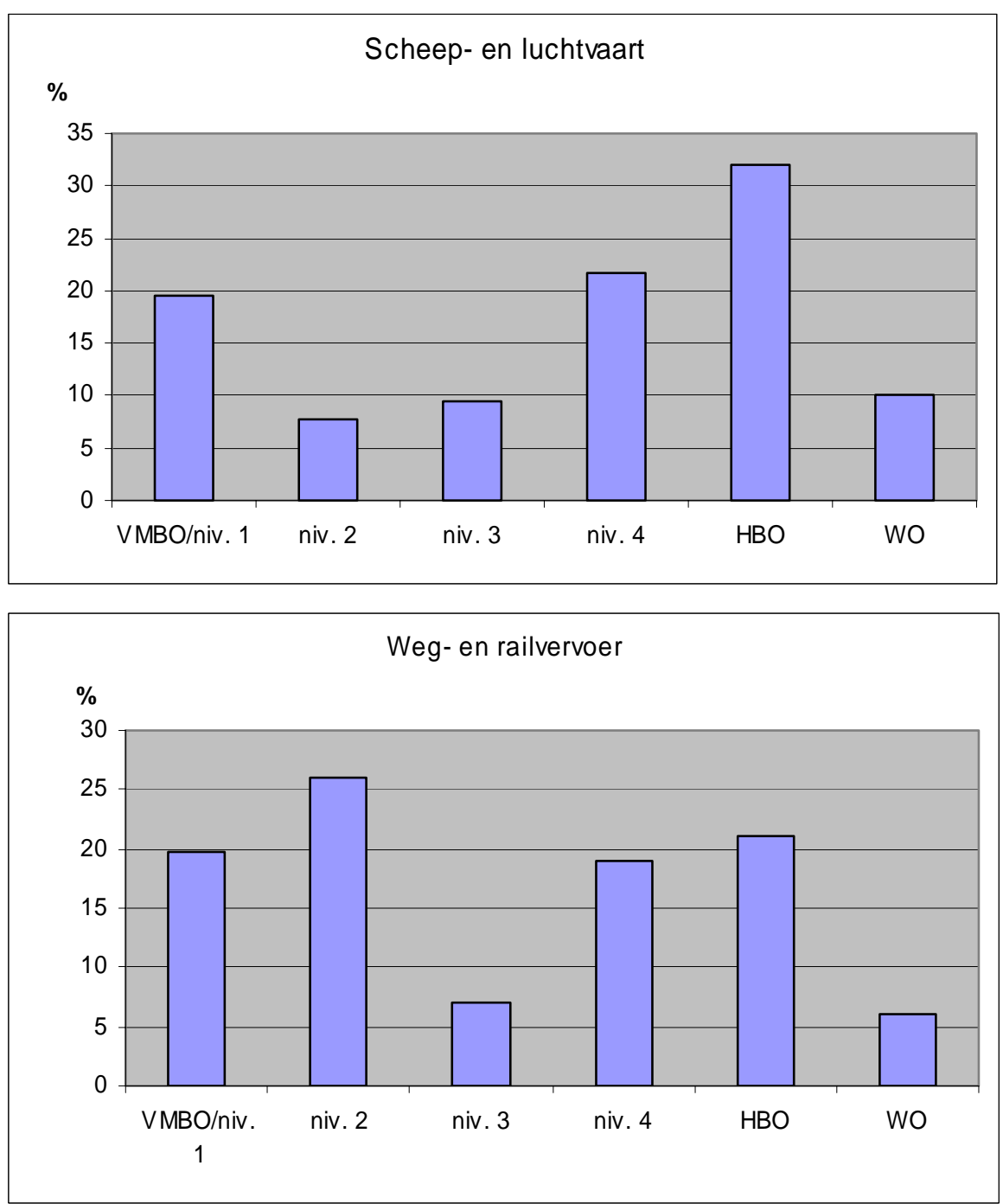


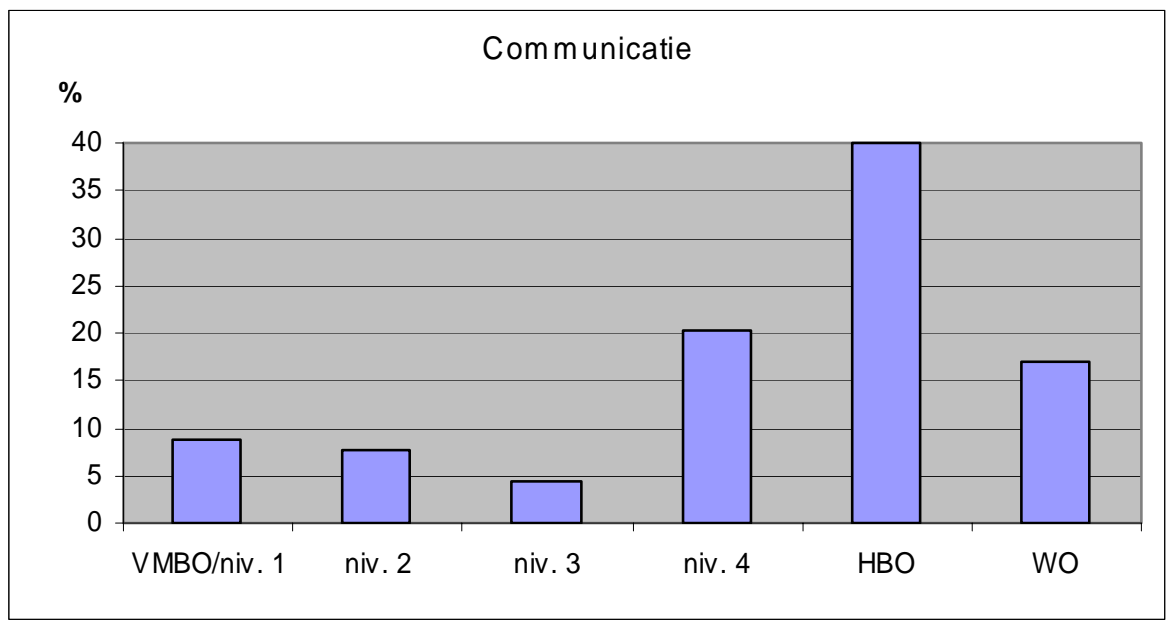

In figuur 3.10 is de verdeling van de instroom van schoolverlaters naar kwalificatieniveau voor het Bank- en verzekeringswezen weergegeven. Het bankwezen werft zijn jonge arbeidskrachten hoofdzakelijk onder schoolverlaters van het hoger onderwijs (73\%). Meer dan de helft van de instromers heeft een HBO-achtergrond. Onder de lager en middelbaar opgeleiden komt niveau 4 het meest voor (16\%). De lagere niveaus komen weinig aan bod. Het Verzekeringswezen laat een soortgelijk beeld zien als het Bankwezen. Alleen is in het Verzekeringswezen het aandeel schoolverlaters met niveau 4 hoger en het aandeel afgestudeerde HBO'ers lager dan in het Bankwezen.

Figuur 3.10

Opleidingsniveau van gediplomeerde schoolverlaters die instromen in het Bank- en verzekeringswezen, 1999-2004

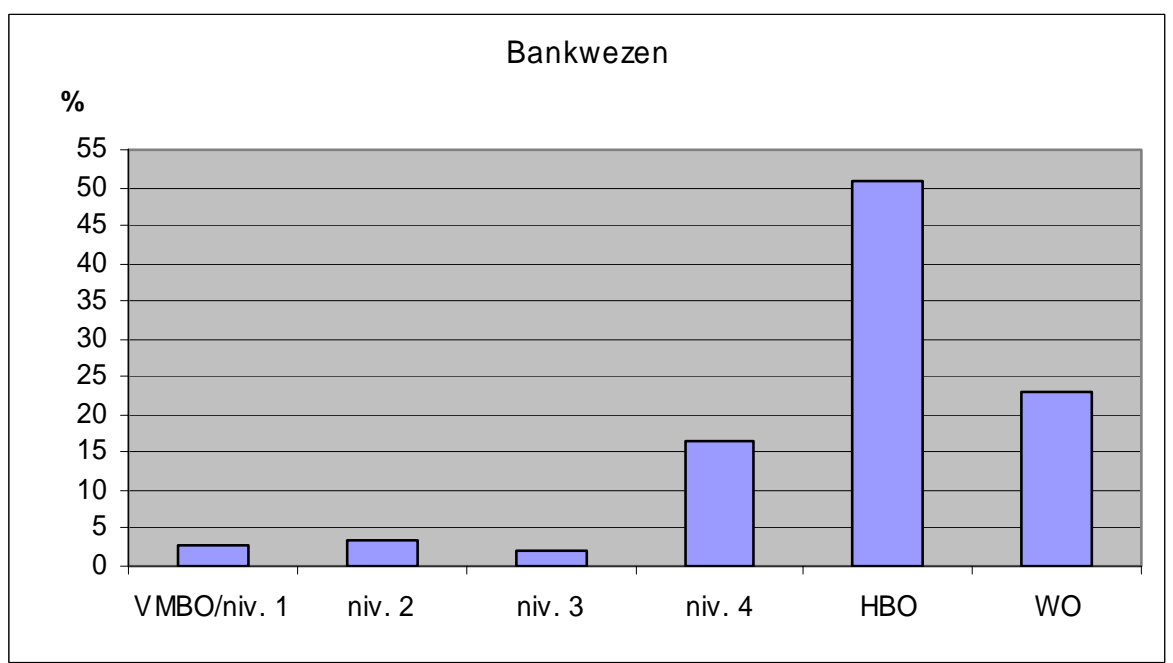




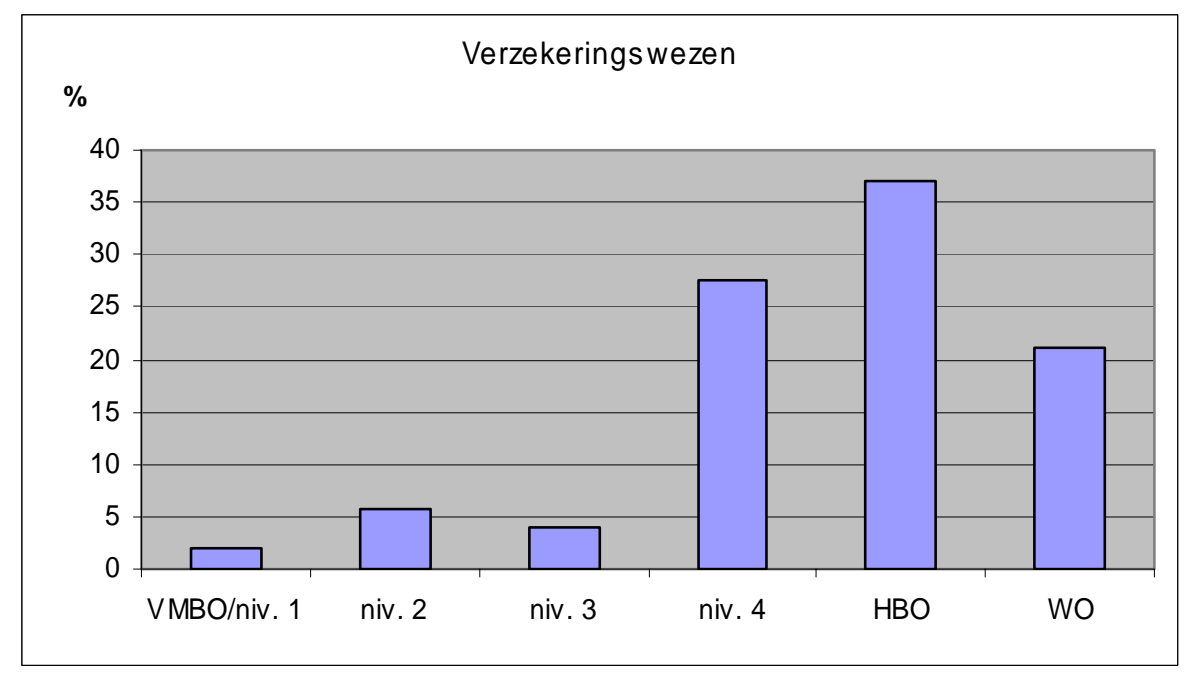

Figuur 3.11 laat de verdeling van de instroom naar kwalificatieniveau zien voor de drie sectoren binnen de Horeca en zakelijke dienstverlening. De sector Horeca werft voornamelijk onder de lager en middelbaar opgeleiden (89\%). Vooral niveau 2 en $\mathrm{VMBO} /$ niveau 1 komen vaak voor onder de schoolverlaters die instromen (respectievelijk 29\% en 27\%).

Figuur 3.11

Opleidingsniveau van gediplomeerde schoolverlaters die instromen in de Horeca en zakelijke dienstverlening, 1999-2004

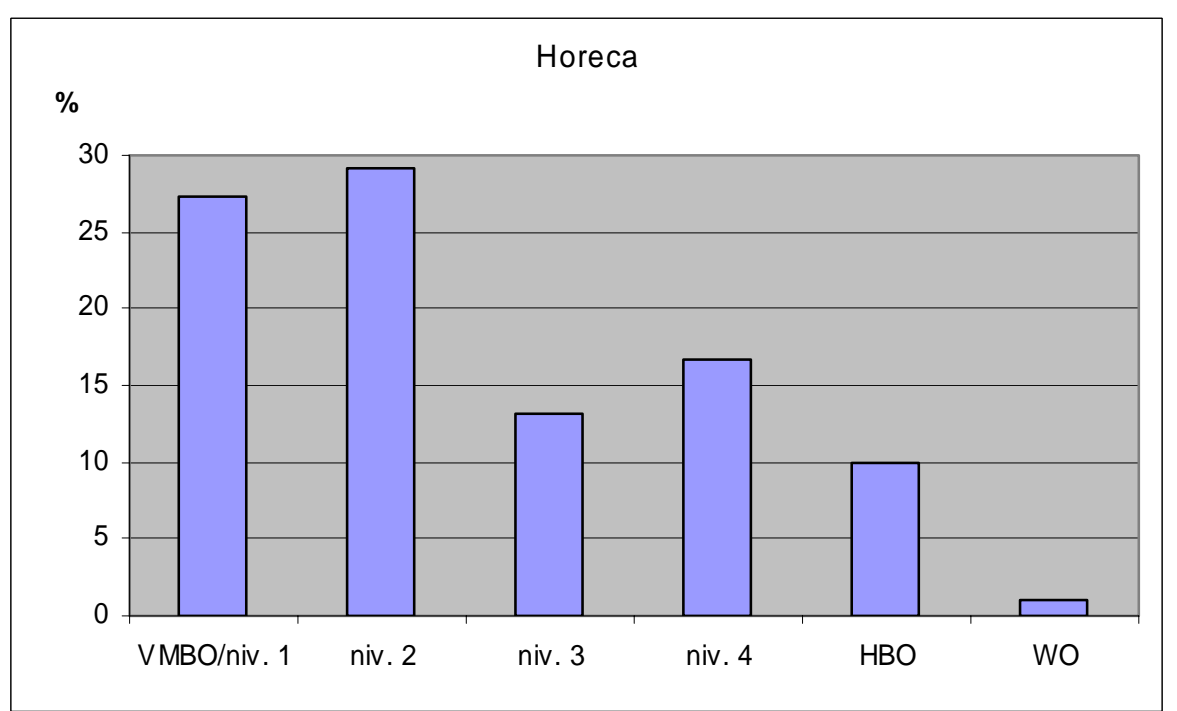



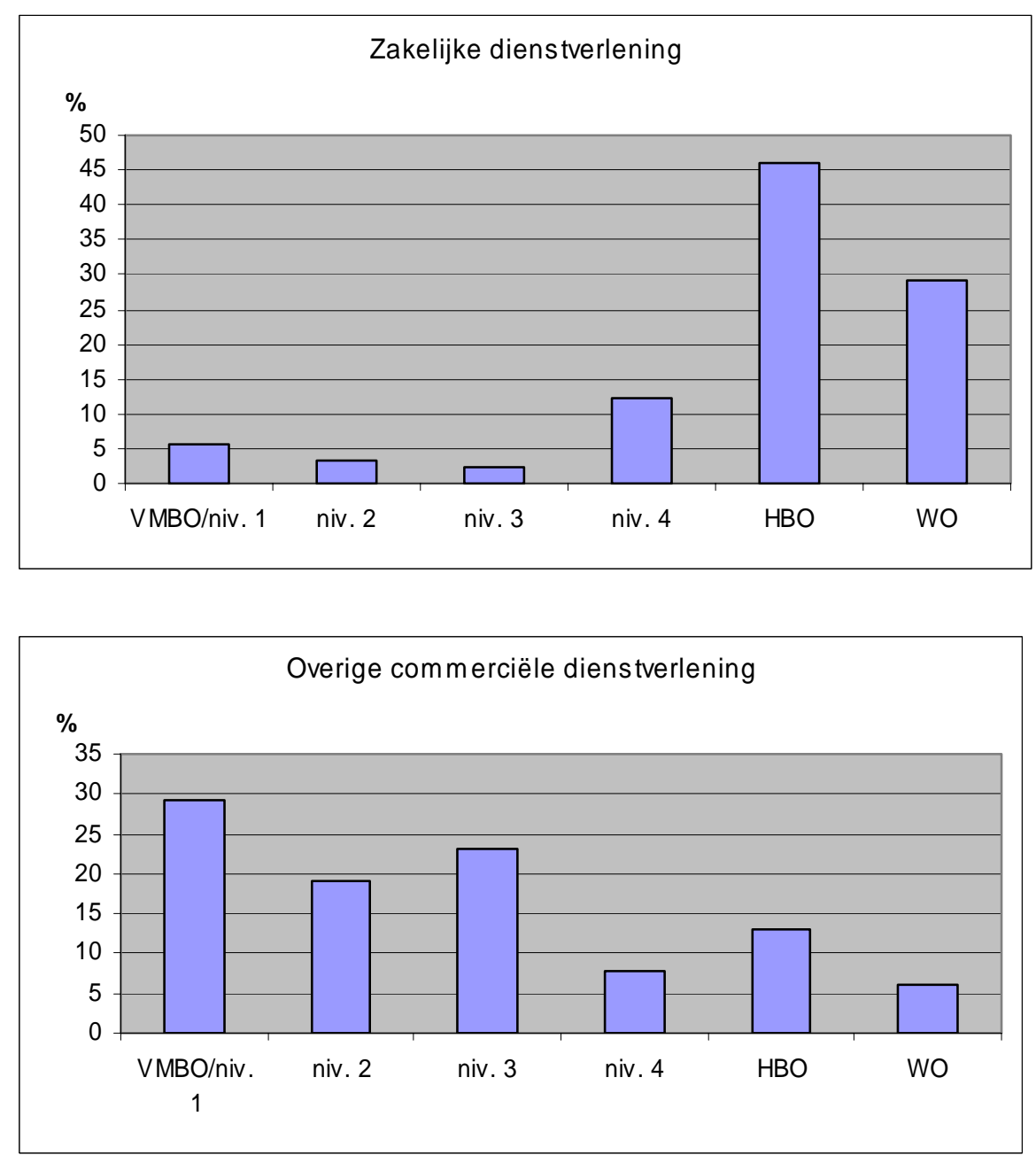

Daarentegen is binnen de Zakelijke dienstverlening drie kwart van de instroom afkomstig van het hoger onderwijs; lager en middelbaar opgeleiden komen dus weinig aan bod. Niveau 4 komt het meeste voor (12\%) binnen de groep lager en middelbaar opgeleiden die instromen.

Onder de werkgevers in de Overige commerciële dienstverlening zijn lager en middelbaar opgeleiden wel in trek. Ongeveer vier van elke vijf schoolverlaters die instromen is lager of middelbaar opgeleid. Daarbij komt het laagste niveau het meeste voor $(29 \%)$, gevolgd door niveau 3.

In figuur 3.12 is voor de twee sectoren binnen de Kwartaire diensten de verdeling van de instroom van schoolverlaters naar opleidingsniveau weergegeven. Ook in de Gezondheidszorg zijn de lager en middelbaar opgeleiden in de meerderheid onder de schoolverlaters die instromen (57\%). Binnen deze sector worden echter 
schoolverlaters van het HBO het vaakst geworven (32\%), gevolgd door schoolverlaters van niveau 4 (22\%) en niveau 3 (19\%).

Figuur 3.12

Opleidingsniveau van gediplomeerde schoolverlaters die instromen in de Kwartaire diensten, 1999-2004
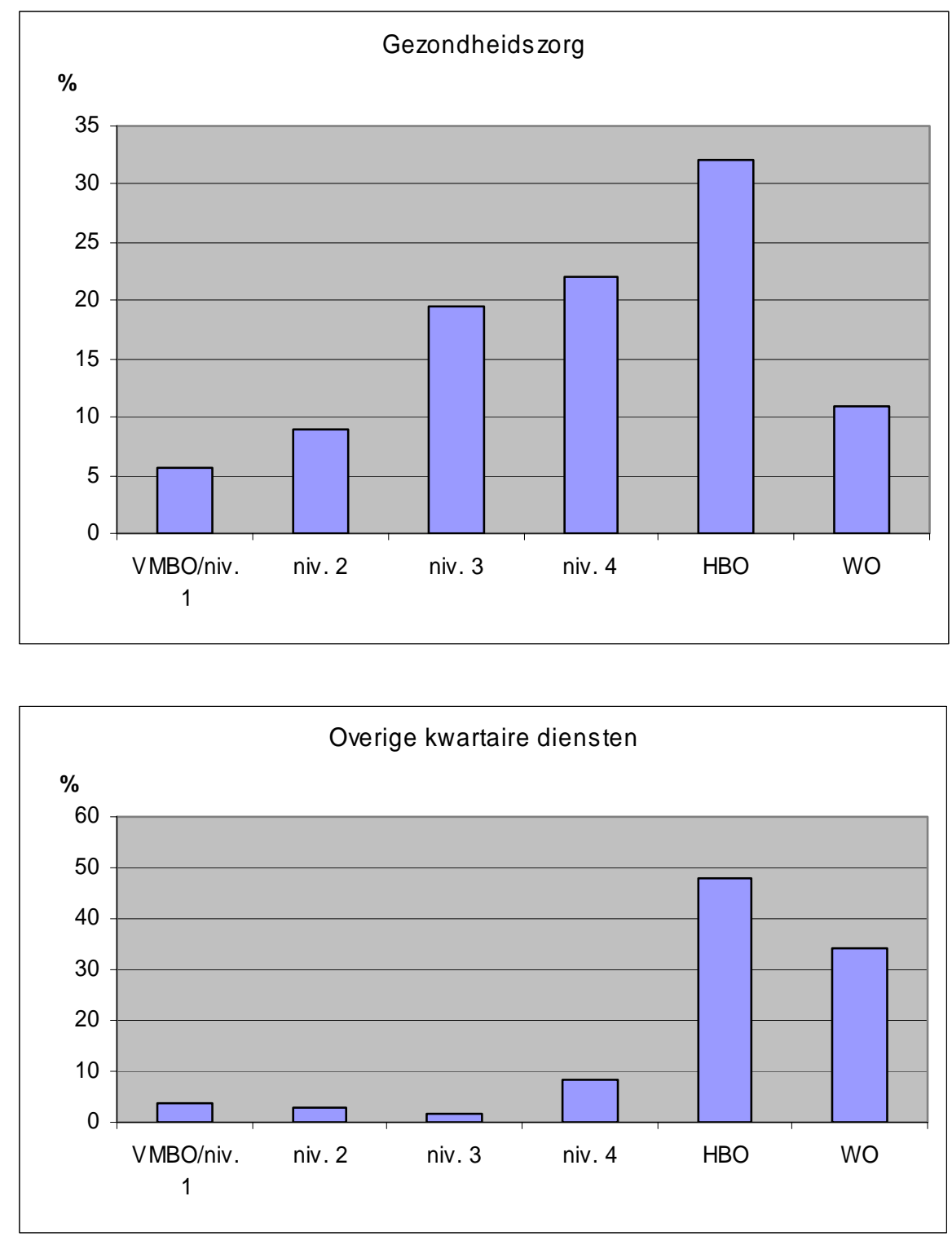

Binnen de Overige kwartaire diensten worden daarentegen relatief weinig lager en middelbaar opgeleiden onder de schoolverlaters geworven (iets meer dan een kwart). Daarbij komt niveau 4 nog het meeste voor: $8 \%$ van de totale instroom van 
schoolverlaters in deze sector. Het aandeel WO'ers in de instroom is het grootst van alle sectoren (34\%).

Tot slot laat figuur 3.13 de verdeling van de instroom van schoolverlaters naar kwalificatieniveau zien voor de sector Onderwijs en overheid. $94 \%$ van de instroom in de sector Onderwijs is hoger opgeleid. Dit is het grootste aandeel van alle sectoren. In de Onderwijssector wordt er dus zelden geworven onder lager en middelbaar opgeleide schoolverlaters. Onder deze groep komt de instroom van schoolverlaters van niveau 4 nog het meeste voor (3\%).

Figuur 3.13

Opleidingsniveau van gediplomeerde schoolverlaters die instromen in Onderwijs en overheid, 1999-2004
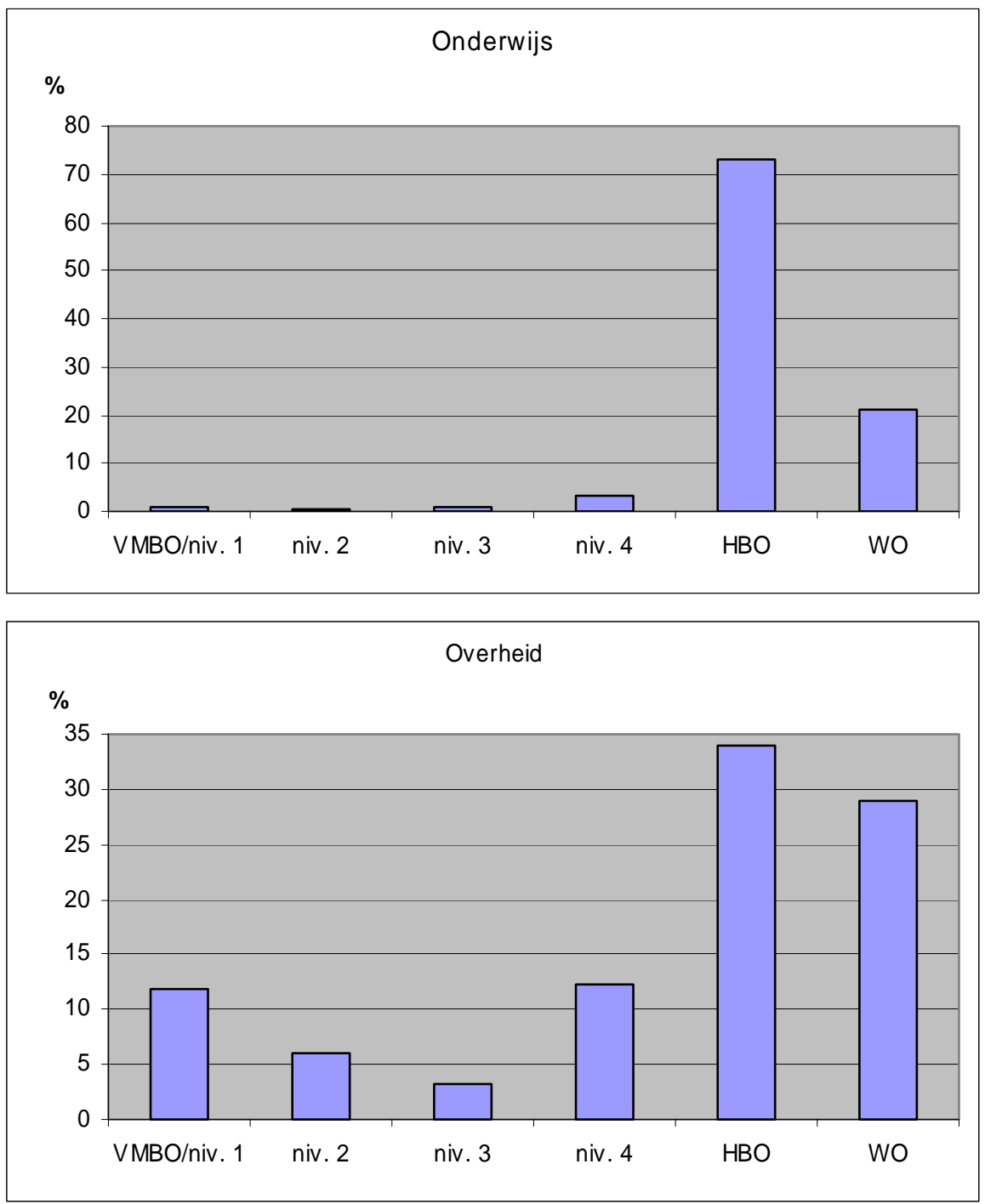
Ook binnen de overheid zijn verreweg de meest instromers hoger opgeleid (63\%). Ook bij de Overheid komt niveau 4 komt onder de lager en middelbaar opgeleide schoolverlaters die instromen het meeste voor. De schoolverlaters van VMBO/niveau 1 maken voor $12 \%$ deel uit (waarbij $4 \%$ niveau 1) van de totale instroom in deze sector.

Aan de hand van de analyse in deze paragraaf kunnen we concluderen dat het HBOniveau in 20 van de 34 bedrijfssectoren het meeste voorkomt als opleidingsniveau onder de schoolverlaters die instromen met een startkwalificatie (i.e. vanaf niveau 2). Niveau 2 is het meest gangbaar in 10 sectoren, terwijl niveau 3 en niveau 4 elk in slechts 2 sectoren het meeste voorkomt.

Ter verklaring van de opleidingenstructuur van de sectoren is nagegaan wat de correlatie is tussen het percentage ingestroomde schoolverlaters van een bepaald opleidingsniveau in een sector met de percentages ingestroomde schoolverlaters van de andere opleidingsniveaus. De correlaties tussen de verschillende opleidingsniveaus zijn weergegeven in tabel 3.1. Het valt op dat vrijwel alle lagere en middelbare opleidingsniveaus tot en met niveau 3 positief met elkaar gecorreleerd zijn. Dat betekent bijvoorbeeld dat sectoren waarin veel schoolverlaters van niveau 2 instromen over het algemeen ook een grote instroom van schoolverlaters van VMBO en niveau 1 laten zien. Het percentage van niveau 4 of HAVO/VWO laat geen statistisch significant verband zien met de percentages schoolverlaters van een ander opleidingsniveau. Daarentegen blijkt dat in sectoren waarin veel HBO'ers en WO'ers instromen, juist weinig lager en middelbaar opgeleiden instromen. Ook is er een sterke positieve correlatie tussen het percentage afgestudeerden van het HBO en het WO dat in een sector instroomt.

Tabel 3.1

Correlaties tussen de percentages van ingestroomde schoolverlaters per opleidingsniveau voor 34 bedrijfssectoren, 1999-2004

\begin{tabular}{llllllll}
\hline $\begin{array}{l}\text { Opleidings- } \\
\text { niveau }\end{array}$ & VMBO & Niv.1 & Niv.2 & Niv.3 & Niv.4 $\begin{array}{l}\text { HAVO/ } \\
\text { VWO }\end{array}$ & HBO & WO
\end{tabular}

\begin{tabular}{|c|c|c|c|c|c|c|c|c|}
\hline VMBO & 1 & & & & & & & \\
\hline Niv.1 & $0,3^{*}$ & 1 & & & & & & \\
\hline Niv.2 & $0,7^{\star \star \star}$ & $0,5^{\star \star \star}$ & 1 & & & & & \\
\hline Niv.3 & $0,4^{* *}$ & 0,1 & $0,3^{*}$ & 1 & & & & \\
\hline Niv.4 & $-0,2$ & $-0,0$ & $-0,1$ & 0,2 & 1 & & & \\
\hline HAVO/VWO & $-0,1$ & $-0,0$ & $-0,1$ & $-0,0$ & 0,2 & 1 & & \\
\hline $\mathrm{HBO}$ & $-0,8^{* * *}$ & $-0,5^{\star \star \star}$ & $-0,8^{\star \star *}$ & $-0,7^{\star \star \star}$ & $-0,2$ & $-0,1$ & 1 & \\
\hline WO & $-0,8^{* * *}$ & $-0,4^{\star *}$ & $-0,8^{* * *}$ & $-0,6^{* * *}$ & $-0,1$ & 0,1 & $0,8^{* * *}$ & 1 \\
\hline
\end{tabular}

* Statistisch significant op 10\%-niveau

** Statistisch significant op 5\%-niveau

*** Statistisch significant op 1\%-niveau 



\section{Onderbenutting van schoolverlaters}

In deze paragraaf werpen we een blik op de onderbenutting van de competenties van de werkzame schoolverlaters die in een sector instromen. De mate van onderbenutting van schoolverlaters kan een indicatie zijn dat een bepaald startniveau voor de schoolverlaters die instromen in een sector weliswaar gangbaar is, maar dat deze schoolverlaters relatief vaak overgekwalificeerd zijn voor het niveau van hun werkzaamheden.

Tabel 5.1 presenteert een overzicht van het meest gangbare opleidingsniveau van gediplomeerde schoolverlaters met minimaal een startkwalificatie (vanaf niveau 2) per bedrijfssector en de mate van onderbenutting van schoolverlaters per opleidingsniveau en bedrijfssector. Het blijkt dat over het algemeen de onderbenutting van afgestudeerden van het $\mathrm{HBO}$ het laagste is. Dit is het geval voor 20 van de 34 sectoren. De instromers vanuit het HBO werken dus relatief vaak op het niveau waarvoor ze gestudeerd hebben. Ook voor schoolverlaters van niveau 4 is de onderbenutting laag. Voor 12 sectoren is de onderbenutting van schoolverlaters van niveau 4 het laagst van alle onderscheiden opleidingsniveaus. Voor de Textielsector heeft niveau 3 de laagste onderbenutting, voor de Horecasector is dat niveau 2.

Verder blijkt dat zowel onder schoolverlaters van niveau 2 als onder WOafgestudeerden de onderbenutting in veel sectoren erg hoog is. Het niveau van de werkzaamheden in de verschillende sectoren blijkt dus vooral te passen bij afgestudeerden van niveau 4 en het $\mathrm{HBO}$, en naarmate het opleidingsniveau meer hiervan afwijkt, zijn de verschillen tussen de vereiste competenties in de baan en de verworven competenties van de gediplomeerde schoolverlaters groter. Aan de onderkant van de arbeidsmarkt is het niveau van de te verrichten werkzaamheden vaak te laag voor gediplomeerde schoolverlaters met niveau 2. Aan de bovenkant van de arbeidsmarkt lijkt voor veel academici een eerste baan een instapfunctie op HBO-niveau te zijn. Na enige tijd zouden de academici binnen de organisatie of sector waar men werkt kunnen doorgroeien naar een hoger functieniveau.

Tot slot blijkt uit de tabel dat voor 25 van de 34 bedrijfssectoren het meest gangbare opleidingsniveau hetzelfde is als het opleidingsniveau met de laagste onderbenutting, of beperkt het verschil zich tot één niveau. Het verschil is groter voor de sectoren Overige voedingsproducten, Kunststofverwerking, Metaalproducten, Transport-middelen, Hout- en bouwmaterialen, Bouw, Handel en reparatie, Weg- en railvervoer en Overige commerciële dienstverlening. Voor een aantal sectoren is de onderbenutting van de schoolverlaters van het meest gangbare opleidingsniveau meer dan $50 \%$. Dit zijn de sectoren Overige voedingsproducten, Transportmiddelen, Textiel, Hout- en bouwmaterialen, Handel en reparatie, Weg- en railvervoer. 
Tabel 5.1

Onderbenutting van gediplomeerde schoolverlaters die instromen in een bedrijfssector als percentage van het totaal aantal instromers op het betreffende opleidingsniveau, afgezet tegen het meest gangbare opleidingsniveau per bedrijfssector, 1999-2004

\begin{tabular}{|c|c|c|c|c|c|c|}
\hline \multirow[b]{2}{*}{ Bedrijfssector } & \multirow{2}{*}{$\begin{array}{r}\text { Meest gangbare } \\
\text { niveau } \\
\text { (vanaf niveau 2) }\end{array}$} & \multirow[b]{2}{*}{ niv. 2} & \multirow[b]{2}{*}{ niv. 3} & \multirow[b]{2}{*}{ niv. 4} & \multicolumn{2}{|c|}{ Onderbenuttin } \\
\hline & & & & & $\mathrm{HBO}$ & wo \\
\hline Tuinbouw & 4 & 71 & 69 & 55 & 47 & 85 \\
\hline Veehouderij & 3 & 44 & 46 & 37 & 41 & 64 \\
\hline Akkerbouw, bosbouw en visserij & 4 & 58 & 57 & 34 & 46 & 64 \\
\hline Vlees- en visverwerking & $\mathrm{HBO}$ & 80 & 55 & 43 & 20 & 30 \\
\hline Overige voedingsproducten & 2 & 53 & 58 & 40 & 25 & 41 \\
\hline Drank en tabaksproducten & $\mathrm{HBO}$ & 50 & 28 & 31 & 26 & 27 \\
\hline Basischemie & $\mathrm{HBO}$ & 26 & 14 & 8 & 20 & 20 \\
\hline Eindproducten chemie & $\mathrm{HBO}$ & 65 & 44 & 27 & 15 & 39 \\
\hline Kunststofverwerking & 2 & 32 & 44 & 15 & 20 & 49 \\
\hline Basismetaal & $\mathrm{HBO}$ & 58 & 17 & 67 & 12 & 21 \\
\hline Metaalproducten & 2 & 45 & 68 & 27 & 22 & 69 \\
\hline Machine-industrie & $\mathrm{HBO}$ & 37 & 48 & 29 & 16 & 48 \\
\hline Elektrotechniek & $\mathrm{HBO}$ & 49 & 67 & 18 & 16 & 45 \\
\hline Transportmiddelen & 2 & 66 & 59 & 30 & 15 & 36 \\
\hline Textiel & 2 & 63 & 15 & 21 & 28 & 53 \\
\hline Hout- en bouwmaterialen & 2 & 51 & 55 & 41 & 25 & 62 \\
\hline Papier & $\mathrm{HBO}$ & 19 & 54 & 31 & 24 & 57 \\
\hline Grafische industrie & $\mathrm{HBO}$ & 32 & 60 & 28 & 24 & 62 \\
\hline Energie & $\mathrm{HBO}$ & 22 & 57 & 19 & 24 & 34 \\
\hline Bouw & 2 & 39 & 58 & 28 & 30 & 54 \\
\hline Exploitatie van onroerend goed & $\mathrm{HBO}$ & 61 & 32 & 23 & 25 & 61 \\
\hline Handel en reparatie & 2 & 56 & 61 & 41 & 38 & 51 \\
\hline Scheep- en luchtvaart & $\mathrm{HBO}$ & 48 & 44 & 26 & 47 & 56 \\
\hline Weg- en railvervoer & 2 & 59 & 48 & 29 & 44 & 61 \\
\hline Communicatie & $\mathrm{HBO}$ & 63 & 53 & 37 & 28 & 50 \\
\hline Bankwezen & $\mathrm{HBO}$ & 17 & 36 & 15 & 22 & 43 \\
\hline Verzekeringswezen & $\mathrm{HBO}$ & 67 & 30 & 26 & 30 & 47 \\
\hline Horeca & 2 & 28 & 31 & 45 & 50 & 92 \\
\hline Zakelijke dienstverlening & $\mathrm{HBO}$ & 45 & 46 & 18 & 14 & 37 \\
\hline Overige commerciële dienstverlening & 3 & 34 & 45 & 41 & 32 & 60 \\
\hline Gezondheidszorg & $\mathrm{HBO}$ & 28 & 21 & 12 & 29 & 22 \\
\hline Overige kwartaire diensten & $\mathrm{HBO}$ & 44 & 43 & 22 & 20 & 35 \\
\hline Onderwijs & $\mathrm{HBO}$ & 42 & 25 & 14 & 5 & 21 \\
\hline Overheid & $\mathrm{HBO}$ & 63 & 58 & 29 & 24 & 44 \\
\hline
\end{tabular}

Opm.: vetgedrukt $=$ opleidingsniveau met de laagste onderbenutting Bron: ROA 


\section{Conclusies}

In dit rapport staat de vraag centraal welk opleidingsniveau het meest gangbaar is voor schoolverlaters die in een bepaalde bedrijfssector instromen. In alle sectoren stromen vanuit het onderwijs schoolverlaters in van heel verschillend opleidingsniveau. Ook de samenstelling van de werkgelegenheid naar opleidingsniveau is heel divers in de verschillende sectoren. Dit illustreert dat productieprocessen binnen sectoren dusdanig complex en heterogeen zijn, dat er veel verschillende soorten competentieniveaus en vaardigheden verlangd worden door werkgevers.

Uit de analyse van de instroom van schoolverlaters naar opleidingsniveau blijkt dat de instroom van schoolverlaters van VMBO, niveau 1, niveau 2 en niveau 3 positief gecorreleerd is. Dat wil bijvoorbeeld zeggen dat bedrijfssectoren die veel schoolverlaters van niveau 2 werven, ook relatief vaak onder schoolverlaters van VMBO, niveau 1 en niveau 3 werven. De instroom van de schoolverlaters van VMBO en niveau $1 / 2 / 3$ is echter negatief gecorreleerd met de instroom van gediplomeerden van het HBO en WO. Een hogere instroom van HBO'ers en WO'ers gaat dus voor de meeste sectoren samen met een lagere instroom op de lagere opleidingsniveaus. De instroom van niveau 4 is wat dat betreft een tussencategorie: deze instroom is noch aan de lagere noch aan de hogere opleidingsniveaus gecorreleerd.

We concluderen dat het HBO-niveau in 20 van de 34 bedrijfssectoren het meeste voorkomt als opleidingsniveau onder de schoolverlaters die instromen met een startkwalificatie (i.e. vanaf niveau 2). Niveau 2 is het meest gangbaar in 10 sectoren, terwijl niveau 3 en niveau 4 elk in slechts 2 sectoren het meeste voorkomen. Hieruit kan tevens geconcludeerd worden dat het gangbare instroomniveau van schoolverlaters veelal hoger ligt dan de startkwalificatie op niveau 2.

Bovendien is voor elke sector gekeken naar de mate waarin schoolverlaters werkzaamheden uitvoeren die ook door schoolverlaters van een lager opleidingsniveau kunnen worden uitgevoerd (onderbenutting). Het blijkt dat over het algemeen de onderbenutting van afgestudeerden van het HBO het laagste is in vergelijking met schoolverlaters van niveau 2, 3, 4 en WO. Dit is het geval voor 20 van de 34 sectoren. De instromers vanuit het HBO werken dus relatief vaak op het niveau waarvoor ze gestudeerd hebben. Ook voor schoolverlaters van niveau 4 is de onderbenutting laag. Voor 12 sectoren is de onderbenutting van schoolverlaters van niveau 4 het laagst van alle onderscheiden opleidingsniveaus. Dit is voor zowel niveau 3 als voor niveau 2 in slechts één sector het geval. Verder blijkt dat zowel onder schoolverlaters van niveau 2 als onder WO-afgestudeerden de onderbenutting in veel sectoren erg hoog is.

Voor 25 van de 34 bedrijfssectoren is het meest gangbare opleidingsniveau onder de instromers hetzelfde als het opleidingsniveau met de laagste onderbenutting, of beperkt het verschil zich tot één niveau. Voor een aantal sectoren is de 
onderbenutting van de schoolverlaters van het meest gangbare opleidingsniveau meer dan $50 \%$. Voor de werkgevers in deze sectoren kan dit een signaal zijn dat de werving van schoolverlaters onvoldoende is afgestemd op het niveau van de uit te voeren werkzaamheden voor deze schoolverlaters. Dit kan bijvoorbeeld tot gevolg hebben dat de arbeidssatisfactie onder deze schoolverlaters lager ligt, en dat er een groter risico is op ziekteverzuim of verloop van personeel. 


\section{Referenties}

Houtkoop, W.A., R.K.W. van der Velden, T.F. Brandsma (2004), De waarde van de startkwalificatie, Max Goote bve, Amsterdam.

ROA (2002), ROA-Classificatiegids 2002, ROA-R-2002/3, Universiteit Maastricht.

ROA (2003), De arbeidsmarkt naar opleiding en beroep tot 2008, ROA-R-2003/11, Universiteit Maastricht.

ROA (2005), Schoolverlaters tussen onderwijs en arbeidsmarkt 2004, Rapport en Statistische Bijlage, ROA-R-2005/6 en ROA-R-2005/6B, Universiteit Maastricht.

Velden, R. van der, R. de Vries, M. Wolbers en P. van Eijs (2002), De waarde van de startkwalificatie, ROA-R-2002/14, Universiteit Maastricht. 



\section{Bijlage A}

Tabel A. 1

Overzicht van kwalificatieniveaus volgens de Wet Educatie en Beroepsonderwijs (WEB)

Niveau Opleiding Duur

in jaren

$1 \quad$ Eenvoudige uitvoerende

Assistentenopleiding

0,5 tot 1

2 Uitvoerende werkzaamheden

Basisberoepsopleiding

2 tot 3

3 Volledige zelfstandige uitvoering

Vakopleiding

2 tot 4

$4 \quad$ Volledige zelfstandige uitvoering

Middenkaderopleiding

3 tot 4 van werkzaamheden met brede inzetbaarheid dan wel specialisatie

Specialistenopleiding (vakopleiding 1 tot 2

of middenkaderopleiding vereist)

Bron: www.minocw.nl/documenten/web1hoofdlijnen.pdf

Niveau 1 van de kwalificatiestructuur binnen de WEB wordt door het CBS (en ook internationaal) niet als middelbaar beroepsniveau beschouwd. In dit rapport wordt niveau 1 tot het lagere opleidingsniveau gerekend van Basisonderwijs (ongeschoolden) en VMBO.

Alle opleidingen uit de kwalificatiestructuur kunnen in principe via twee leerwegen worden gevolgd:

- Een beroepsopleidende leerweg (bol), waarbij de omvang van de beroepspraktijkvorming tussen de twintig en zestig procent ligt;

- Een beroepsbegeleidende leerweg (bbl, het voormalige leerlingwezen), waarbij het percentage beroepspraktijkvorming meer dan zestig procent is. 



\section{Bijlage B}

Tabel B.1

Percentage werkenden naar opleidingsniveau in 34 bedrijfssectoren, gemiddelde 2003-2004

\begin{tabular}{|c|c|c|c|c|c|c|}
\hline Bedrijfssector & $\mathrm{BO}$ & VMBO & $\mathrm{MBO}^{*}$ & $\mathrm{HBO}$ & WO & $\begin{array}{r}\text { Totaal aantal } \\
\text { werkenden }\end{array}$ \\
\hline Tuinbouw** & 12 & 42 & 40 & 4 & 2 & 65.000 \\
\hline Veehouderij ${ }^{\star \star}$ & 6 & 31 & 54 & 8 & 1 & 101.000 \\
\hline Akkerbouw, bosbouw en visserij ${ }^{\star *}$ & 9 & 33 & 46 & 9 & 3 & 23.000 \\
\hline Vlees- en visverwerking & 18 & 30 & 40 & 9 & 3 & 35.500 \\
\hline Overige voedingsproducten & 10 & 31 & 44 & 11 & 5 & 92.000 \\
\hline Drank en tabaksproducten & 4 & 18 & 47 & 18 & 11 & 16.000 \\
\hline Basischemie & 4 & 11 & 49 & 23 & 14 & 39.500 \\
\hline Eindproducten chemie & 5 & 13 & 44 & 23 & 14 & 41.500 \\
\hline Kunststofverwerking & 11 & 29 & 46 & 10 & 3 & 36.500 \\
\hline Basismetaal & 8 & 24 & 47 & 12 & 9 & 23.000 \\
\hline Metaalproducten & 7 & 31 & 47 & 11 & 3 & 160.000 \\
\hline Machine-industrie & 3 & 23 & 51 & 18 & 5 & 74.500 \\
\hline Elektrotechniek & 4 & 17 & 39 & 26 & 14 & 76000 \\
\hline Transportmiddelen & 7 & 28 & 46 & 13 & 5 & 55.500 \\
\hline Textiel & 13 & 33 & 41 & 8 & 4 & 21.000 \\
\hline Hout- en bouwmaterialen & 19 & 30 & 38 & 8 & 3 & 194.500 \\
\hline Papier & 8 & 31 & 44 & 12 & 4 & 24.500 \\
\hline Grafische industrie & 5 & 19 & 50 & 15 & 11 & 96.000 \\
\hline Energie & 3 & 13 & 52 & 22 & 10 & 52.000 \\
\hline Bouw & 8 & 31 & 51 & 8 & 2 & 455.500 \\
\hline Exploitatie van onroerend goed & 3 & 12 & 49 & 27 & 10 & 68.500 \\
\hline Handel en reparatie & 6 & 30 & 50 & 10 & 3 & 978.500 \\
\hline Scheep- en luchtvaart & 4 & 11 & 45 & 33 & 7 & 52.500 \\
\hline Weg-en railvervoer & 9 & 33 & 45 & 9 & 3 & 269.000 \\
\hline Communicatie & 6 & 27 & 43 & 14 & 9 & 118.000 \\
\hline Bankwezen & 1 & 10 & 44 & 26 & 18 & 164.000 \\
\hline Verzekeringswezen & 1 & 12 & 50 & 23 & 13 & 98.000 \\
\hline Horeca & 10 & 29 & 50 & 8 & 2 & 209.500 \\
\hline Zakelijke dienstverlening & 5 & 13 & 37 & 24 & 21 & 776.000 \\
\hline Overige commerciële dienstverlening & 5 & 22 & 54 & 13 & 6 & 151.500 \\
\hline Gezondheidszorg & 3 & 12 & 47 & 26 & 12 & 1041000 \\
\hline Overige kwartaire diensten & 2 & 10 & 30 & 30 & 28 & 163.500 \\
\hline Onderwijs & 1 & 4 & 17 & 54 & 23 & 485.500 \\
\hline Overheid & 2 & 13 & 45 & 22 & 18 & 544.500 \\
\hline Bedrijfssectoren totaal & 5 & 20 & 44 & 20 & 11 & 7.075 .000 \\
\hline
\end{tabular}

* Incl. HAVO / VWO, excl. BOL/BBL niveau 1.

** Totaal aantal werkenden heeft betrekking op 2002-2003

Bron: ROA/CBS

Zie voor de sectorindeling: ROA(2002). 



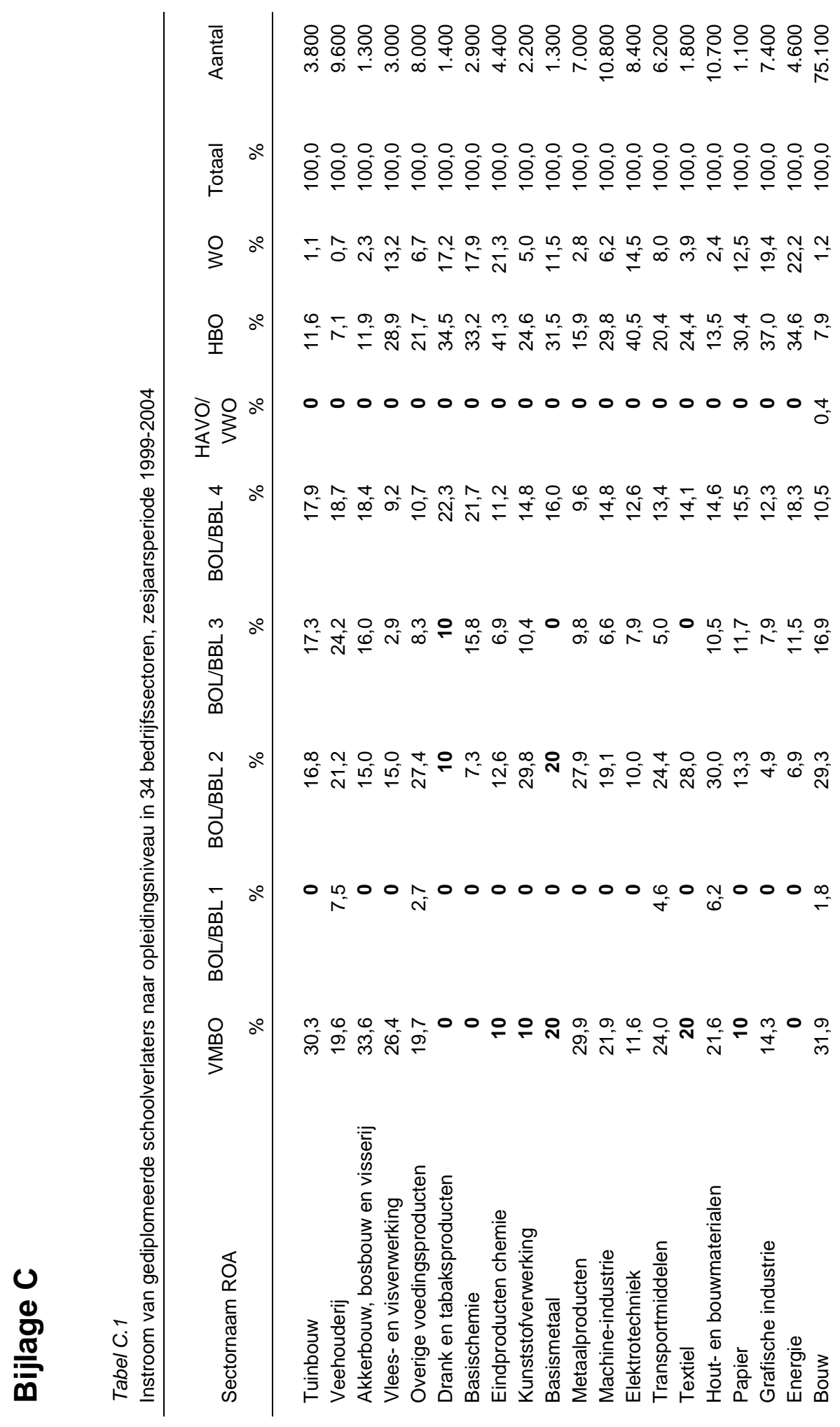




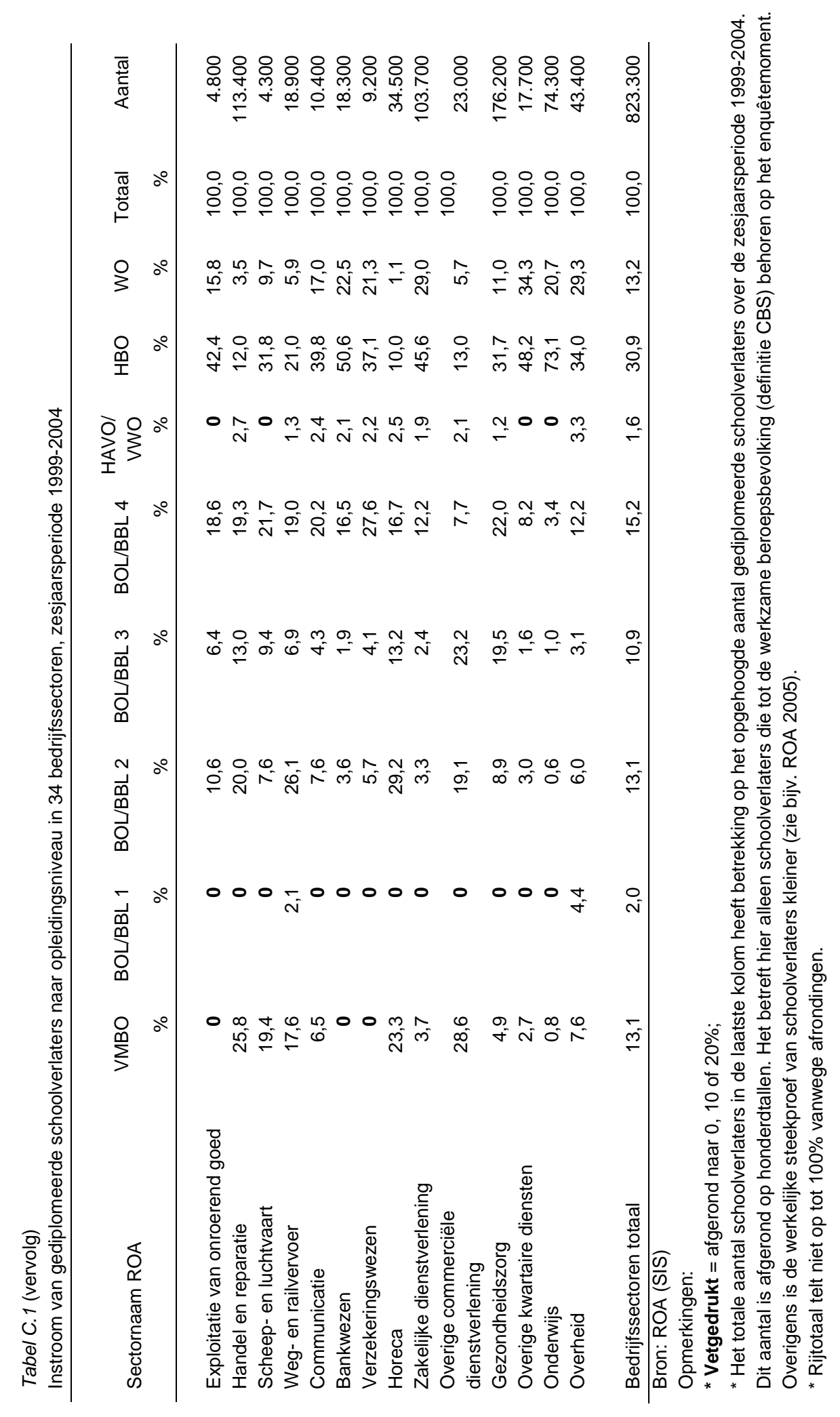

